\title{
The affiliation of Hexasterias problematica and Halodinium verrucatum sp. nov. to ciliate cysts based on molecular phylogeny and cyst wall composition
}

\author{
Gurdebeke Pieter R. ${ }^{1,}{ }^{*}$, Mertens Kenneth ${ }^{2}$, Takano Yoshihito ${ }^{3}$, Yamaguchi Aika ${ }^{4}$, Bogus Kara 5, 6 , \\ Dunthorn Micah ${ }^{7}$, Matsuoka Kazumi ${ }^{3}$, Vrielinck Henk ${ }^{8}$, Louwye Stephen ${ }^{1}$
}

1 Univ Ghent, Dept Geol, Krijgslaan 281, B-9000 Ghent, Belgium.

2 Ifremer, Stn Biol Marine, LER BO, PI Croix,BP40537, F-29185 Concarneau, France.

3 Inst East China Sea Res ECSER, 1-14 Bunkyo Machi, Nagasaki 8528521, Japan.

${ }^{4}$ Kobe Univ, Res Ctr Inland Seas, Kobe, Hyogo 6578501, Japan.

5 Univ Nottingham, Sch Geog, Ctr Environm Geochem, Nottingham NG7 2RD, England.

6 Texas A\&M Univ, Int Ocean Discovery Program, College Stn, TX 77845 USA.

7 Univ Kaiserslautern, Dept Ecol, Erwin Schrodinger St, D-67663 Kaiserslautern, Germany.

8 Univ Ghent, Dept Solid State Sci, Krijgslaan 281,S1, B-9000 Ghent, Belgium.

* Corresponding author : Pieter R. Gurdebeke, email address : pieter.gurdebeke@ugent.be

\begin{abstract}
:
Species in the genera Hexasterias and Halodinium have been recorded over the last decades as acritarchs in palynological and/or plankton studies. In paleoenvironmental studies, these resting stages are often interpreted as indicators of freshwater input. The biological affinity of these genera has never been definitely established. Here, a new species, Halodinium verrucatum sp. nov., is described and molecular evidence (single specimen SSU and LSU rDNA sequencing) reveals that both this new species and Hexasterias problematica, collected from sediment samples in the Skagerrak and Baltic Sea, are resting stages of prorodontid ciliates. Additionally, infrared spectroscopic analysis (micro-FTIR) of Hexasterias problematica and Halodinium spp. specimens indicates a carbohydrate-based composition of the cyst wall with evidence for nitrogen-containing functional groups. A similar composition is recorded for tintinnid loricae, which further supports the placement of Hexasterias and Halodinium as ciliate cysts, and the composition is consistent with the heterotrophic nature of ciliates. The morphologically similar species Radiosperma corbiferum has a comparable composition, suggesting a similar ciliate affinity and indicating the utility of micro-FTIR in understanding acritarch affinity. Hexasterias problematica typically occurs in coastal waters from temperate to arctic regions. Halodinium verrucatum sp. nov. is observed in temperate estuarine sediments in the northern hemisphere.
\end{abstract}




\section{Highlights}

- Halodinium verrucatum sp. nov. is described, Hexasterias problematica is emended. $\$$ LSU and SSU rDNA is obtained for Halodinium verrucatum and Hexasterias problematica. Molecular phylogeny and DAPI-staining demonstrate these are ciliate resting cysts. micro-FTIR of resting cysts and tintinid loricae supports this affiliation. The distribution and ecology of both palynomorphs is discussed.

Keywords : Acritarch, Ciliate cyst, FTIR, LSU-SSU rDNA, Prostomatida, Taxonomy 


\section{Introduction}

The informal group of Acritarcha was introduced by Evitt (1963, p. 300) to accommodate organicwalled microfossil remains (i.e., palynomorphs) of apparently unicellular organisms whose biological affinity is unknown and which are resistant to degradation and palynological treatment. Acritarchs consist of a central cavity enclosed by a single- or multilayered wall and are extremely variable in general shape, symmetry, structure, ornamentation and opening of the central cavity (e.g., pore, slit, rupture, pylome). They occur in Proterozoic to modern sediments, and are considered polyphyletic with diverse biological affinities (e.g., Servais 1996). Many palynomorphs originally classified as acritarchs have since been reassigned to other groups, particularly dinoflagellates (e.g., Dale 1977; Colbath and Grenfell 1995), chlorophytes (e.g., Aroui et al. 1999; Kaźmierczak and Kremer 1999; Moczydłowska et al. 2011) and copepod eggs (e.g., McMinn et al. 1992; Van Waveren and Marcus 1993). For fossil species, arguments for these assignments are based on morphological and ultrastructural observations through light microscopy (LM), scanning electron microscopy (SEM) and transmission electron microscopy (TEM) (e.g., Colbath and Grenfell 1995; Willman 2009) and chemical composition through spectroscopic methods (e.g., Marshall et al. 2005; Javaux and Marshall 2006). For species in surface sediments, these are complemented by cytological observations, life history information through incubation experiments and molecular data obtained through methods such as single-cell polymerase chain reaction (PCR) (e.g., Takano and Horiguchi 2005). Hexasterias problematica (syn. Polyasterias problematica) and species of the genus Halodinium are considered to be acritarchs and are often reported in surface sediments. The former species is also known from plankton studies and Halodinium has an extensive fossil record in the late Cenozoic. Hypotheses about their biological affinity have varied widely but were never established conclusively.

Ciliates (phylum Ciliophora) are morphologically diverse heterotrophic unicellular eukaryotes (protozoans) that occur in nearly all moist and aquatic environments from soils, freshwater ponds and lakes to estuaries and the open ocean (e.g., Lynn 2008; Foissner et al. 2008). 
An important synapomorphy of ciliates is nuclear dualism, in which a micro- and macronucleus can cysts as part of their life cycle, often as a response to adverse conditions (Verni and Rosati 2011). These cysts are often more resistant to destruction than any other stage of the life cycle and thus offer higher potential for preservation and fossilization (Dunthorn et al. 2015). The class Spirotrichea is particularly known to produce cysts (Reid and John 1978, 1983). In addition to cysts, the tintinnid ciliates (Class Spirotrichea, Order Tintinnida) are known to have a long fossil record due to their loricae, protective tubular structures that contain the ciliate body throughout the life cycle (Dolan et al. 2013). The chemical composition of ciliate cyst walls is poorly known and limited to a small number of species. Thus far, the major components are characterized as (glyco)proteins and carbohydrates (Wang et al. 2017). Some ciliates are known to cause disease in other organisms (e.g. Lynn 2008), and the management of, for example, sea itch, caused by the parasitic ciliate Cryptocaryon irritans, is difficult because of the complexity of the life cycle involving a resting cyst stage (Ma et al. 2017). Clearly, better understanding of ciliate life cycles and resting cyst stages is of interest to workers in a broad range of fields.

In this study, living and empty Hexasterias problematica cysts were isolated from the surface sediment of a low salinity site in SW Finland. Also, the new Halodinium species, $H$. verrucatum sp. nov. is described from living and empty cysts isolated from surface sediments in a brackish fjord within the Skagerrak, on the west coast of Sweden. Both species are shown, through molecular phylogenetics based on single-cell polymerase chain reaction (PCR) of partial large (LSU) and complete short (SSU) subunit ribosomal DNA (rDNA), to belong to the ciliate order Prorodontida. Staining using the fluorescent 4'-6-diamidino-2-phenylindole (DAPI) was done to confirm this placement. The geochemical composition of the cyst walls was analyzed through micro-Fourier transform infrared (FTIR) spectroscopy and compared with loricae of tintinnid ciliates and with morphologically similar palynomorphs. The species' distributions are assessed 
though a literature review and new observations, and the paleoenvironmental application is evaluated.

\section{Material and Methods}

\section{Sediment sampling, cyst extraction and microscopic observations}

For the study of Hexasterias problematica, surface sediment was collected from Sällvik (28 October 2011), a freshwater-influenced low salinity estuary off southwestern Finland with a halocline at $10 \mathrm{~m}$ depth and salinities up to $4.6 \mathrm{psu}$ in deeper waters (e.g. Heiskanen and Tallberg 1999), using a Limnos gravity corer (Table 1, Fig. 1). For Halodinium verrucatum sp. nov., surface sediment was collected from station Strö 1, south of Havstensund (Skagerrak) using a boxcore (Table 1, Fig. 1). Additional samples from the Skagarrak and Brittany were collected for further observations (Table 1, Fig. 1). All samples were stored in sterile plastic bags at $4{ }^{\circ} \mathrm{C}$.

About $0.5-1.0 \mathrm{~cm}^{3}$ of wet sediment was immersed in filtered seawater and after ultrasonication $\left(60 \mathrm{~s}\right.$, As One ${ }^{\mathrm{TM}} \mathrm{US} 2 \mathrm{R}$ ultrasonic bath), the sediment was rinsed using filtered seawater through a calibrated metallic-mesh Sanpo ${ }^{\mathrm{TM}}$ sieve with a $20 \mu \mathrm{m}$ mesh. From this residue, the cyst fraction was separated using sodium polytungstate (SPT) at a density of $1.3 \mathrm{~g} \mathrm{~cm}^{-1}$ (Bolch 1997). For microscopic observations and geochemical measurements, residues were prepared using a palynological method similar to that described in Mertens et al. (2009a), involving hydrochloric and hydrofluoric acids and no oxidizing agents.

The LM observations, measurements, and photography were made using a MRc5 camera mounted on a Zeiss Axio Imager A1 (400× and $1000 \times$ magnification) at Ghent University. For SEM observations, single cysts were picked from the residue and mounted on a glass slide or filtered on polycarbonate membrane filters (Millipore, Billerica, MA, USA, GTTP Isopore, $0.22 \mu \mathrm{m}$ pore size), sputter coated with gold, and examined with a Zeiss SIGMA300 Gemini field emission SEM at the Station de Biologie Marine (Ifremer, Concarneau, France). The terminology for describing the morphology of Hexasterias and Halodinium is clarified in Fig. 2. 


\section{Molecular analyses}

Four specimens of Hexasterias problematica were isolated for single-cell analysis from the Sällvik sediment sample. Two specimens of Halodinium verrucatum sp. nov. were isolated for single-cell PCR from the Strö 1 sediment sample of Skagerrak. Cysts were photographed and measured using an Olympus BX51 LM with a Nikon digital sight DS-1L 1 module with 100x oil immersion objectives. Subsequently, the cysts were transferred to an inverted LM, crushed with a fine glass needle, and subsequently transferred into a $200 \mu \mathrm{L}$ PCR tube containing $3 \mu \mathrm{L}$ of Milli-Q water. Sequences of partial LSU and SSU rDNA were determined from single cysts. In the first PCR round, the external primers (SR1 and LSU R2; Takano and Horiguchi 2005) were used with PCR mixtures of KOD-Plus-Ver. 2 Kit (Toyobo, Osaka, Japan) under PCR conditions: one initial cycle of denaturation at $94^{\circ} \mathrm{C}$ for $2 \mathrm{~min}$, followed by 35 cycles of denaturation at $94^{\circ} \mathrm{C}$ for $30 \mathrm{~s}$, annealing at $55^{\circ} \mathrm{C}$ for $30 \mathrm{~s}$, and extension at $72^{\circ} \mathrm{C}$ for $2 \mathrm{~min}$ and final extension at $72^{\circ} \mathrm{C}$ for $5 \mathrm{~min}$. In the second PCR, five sets of primers (SR1-SR9, SR4-SR12, SR8-25F1R, SR12cF-25R1 and LSU D1RLSU R2; Takano and Horiguchi 2005) were used with PCR mixtures of KOD-Plus-Ver. 2 Kit (Toyobo, Osaka, Japan), $0.5 \mu \mathrm{L}$ of the first round PCR product as the DNA template, and the same PCR conditions except that the extension at $72^{\circ} \mathrm{C}$ was for $1 \mathrm{~min}$. In the third PCR, five sets of primers (SR-1c-SR5, SR4-SR9, SR8-SR12, LSU D1R-25R1 and LSU D3A-LSU R2; Takano and Horiguchi 2005) were used with PCR mixtures of the TaKaRa EX taq system (Takara Bio Inc., Shiga, Japan), $0.5 \mu \mathrm{L}$ of the second round PCR products as the DNA template, and the same PCR conditions except that the extension at $72^{\circ} \mathrm{C}$ was for $30 \mathrm{~s}$. PCR products were sequenced directly using the ABI PRISM BigDye Terminator Cycle Sequencing Kit (Perkin-Elmer, Foster City, CA, USA).

\section{Sequence alignments and phylogenetic analyses}


After an initial analysis containing taxa from all major ciliate groups based on Dunthorn et al. (2014), a final sampling of 26 SSU-rDNA accessions from the Prostomatea, plus two outgroup species (Furgasonia blochmanni and Platyophrya vorax) was based on Yi et al. (2010). Nucleotides were aligned and ambiguous positions masked with GUIDANCE v1.1 (Penn et al. 2010a,b). The GTR-I-G evolutionary model was the best fit model selected by the Akaike information criterion (AIC) as implemented in jModeltest2 v0.1 (Darriba et al. 2012; Guindon and Gascuel 2003). Maximum Likehood (ML) analyses were carried out in RAxML-HPC v7.2.5 (Stamatakis et al. 2008), with bipartition support from 1000 multiparametic bootstrap replicates.

\section{DAPI Staining}

For DNA-specific fluorescent DAPI staining (Kapuscinski, 1995), a specimen of Hexasterias problematica was extracted from fresh sediments from the Vilaine Estuary (Brittany). The cyst was slightly crushed by pressing down the coverslip to allow the DAPI to intrude. Observation and imaging was done on a Olympus BX41 microscope with 100× oil immersion objectives (Ifremer, Concarneau).

\section{Geochemical analysis of cyst wall composition}

For micro-FTIR geochemical analysis of Halodinium spp., palynological residue was used from Skagerrak (Strö 1 station), Brittany (France) and the Irish Sea (see Mertens et al. 2009b and Gurdebeke et al., accepted, for sampling details), and from Brittany (France) and southern France for Hexasterias problematica (see Mertens et al. 2009b; Gurdebeke et al., accepted and Mertens et al. 2017, respectively for sampling details). For comparison, additional FTIR spectra were measured on specimens of the acritarch Radiosperma corbiferum from Brittany, the Irish Sea (Mertens et al. 2009b; Gurdebeke et al., accepted for sampling details) and the Baltic Sea (see Mertens et al. 2012a for details) and on loricae of the tintinnid ciliates Parafavella sp. from the Skagerrak (Strö 1 station, mentioned above) and Stenosemella sp. from the German Wadden Sea (see Bogus et al. 2014 for 
sampling details). Between palynological processing and the preparation for FTIR, these residues were stored in cool and dark conditions without adding conservation chemicals such as copper sulphate or fungicides.

The palynological residues were treated as described in Gurdebeke et al. (accepted). They were ultrasonicated for $30 \mathrm{~s}$ and rinsed three times with organic solvents (methanol and dichloromethane, 1:1 in volume) and MilliQ water over a $20 \mu \mathrm{m}$ mesh to remove polar and apolar compounds that might have adhered to the outside of the cyst walls. Visually clean individual cysts were manually isolated, placed on an Au-coated mirror and dried. Specimens were analyzed with a Bruker Hyperion 2000 microscope coupled to a Bruker Vertex 80v FTIR spectrometer at the Department of Solid State Sciences of Ghent University. Magnification of the microscope was set at $15 \times$ and the aperture at $100 \times 100 \mu \mathrm{m}$. The combination of detector (liquid $\mathrm{N}_{2}$ cooled MCT detector), source (Globar) and beamsplitter $(\mathrm{KBr})$ settings restrict the effective infrared spectral range examined to $\sim 4000-650 \mathrm{~cm}^{-1}$. All presented spectra are recorded in reflection mode (deposits on the Au mirror), at a resolution of $2 \mathrm{~cm}^{-1}$, and averaged over 100 scans.

Data were analyzed with OPUSC spectroscopy software (Bruker 2014). The presented absorbance spectra were obtained after background (direct reflection on the Au mirror) subtraction, atmospheric correction and baseline correction using a rubberband correction method using polynomes. Functional groups were identified based on comparison with Colthup et al. (1990) and published data (e.g., Bogus et al. 2014; Cárdenas et al. 2004).

\section{Results}

\section{Species description}

Phylum Ciliophora Doflein, 1901

Class Prostomatea Schewiakoff, 1896

Order Prorodontida Corliss, 1974

Genus Hexasterias Cleve, 1900 emend. 
Synonymy.

1900 Hexasterias problematica Cl. - Cleve, K. Sven. Vetenskapsakad. Handl. 32: 22 (original description of genus and species).

1910 Polyasterias g.n. - Meunier, Microplancton, p. 87 (junior objective synonym; unjustified replacement name for Hexasterias).

Type species. Hexasterias problematica Cleve, 1910

Improved diagnosis. Organic-walled cyst with bilayered wall and subspherical to flattened central body from which coplanar radial processes arise from inner wall, are hollow and not connected proximally or distally. Circular pylome in polar position, parallel to the process plane.

Remarks. Cleve (1900) gave no formal description of the genus Hexasterias, which is why a diagnosis is provided here. Meunier (1910), who studied plankton from the Barents and Kara seas, proposed changing the genus name to Polyasterias, to emphasize that the number of projections is often not six (instead ranging from four to eight). This is an unjustified replacement and thus Polyasterias is an objective junior synonym of Hexasterias.

Species classified in Hexasterias. Hexasterias problematica Cleve, 1900. A second species, Hexasterias spina-trifida, was described by Wright (1907, p. 9, Plate 3, Fig. 6), but it is not clear if it has any affinity to H. problematica. Likewise for Polyasterias simplex of Kufferath (1950).

Hexasterias problematica Cleve ,1900 emend.

Figs. 3a-c; Table 2.

1887 'Röhrenstatoblast' - Hensen, Ber. Komm. Wiss. Unters. Meere 5: 67, Plate IV, Fig. 27 (first illustration).

1897 'Dornige cyste' - Vanhöffen, Die Fauna und Flora Grönlands: 287, Plate VI, Fig. 3 (record from Egersund Fjord, Norway, with illustration).

1900 Hexasterias problematica Cl. - Cleve, K. Sven. Vetenskapsakad. Handl. 32: 22 (original description, probably no type material available). 
1904 'Ovum hispidum problematicum' (Clev.) Lohm. - Lohmann, Eier und sogenannte Cysten der Plankton-Expedition: 32, Pl. 5, Figs. 2, 4 (invalid by implication, as the genus was not validly published, see Williams et al. 2017, p. 920).

1905 Xanthidium coronatum nov. sp. - Pavillard, Dissertation: 60, P1. 3, Figs. 2-3 (invalid because the name was already occupied: Xanthidinium coronatum Ehrenberg, 1843, Verbr. und Einfluss des Mikrosk. Lebens in Süd- und Nord-Amerika, Pl. 4, Fig. 26).

1907 Hexasterias problematica Cleve - Wright, Contrib. Can. Biol. Fish. 1: 8, Pl. 3, Fig. 5 (record from eastern Nova Scotia, with illustration).

1910 Polyasterias problematica (Cleve) pro parte - Meunier, Microplancton: 87, P1. 5, Figs. 2022 (redescription and combination with superfluous replacement name Polyasterias).

1919 Polyasterias problematica Meunier - Meunier, Mém. Mus. r. his. nat. Belg. 8: 40, Pl. 23, Figs. 19-20 (record from the Belgian coast, with illustration).

1961 Polyasterias problematica (Cleve) Meunier - Bursa, J. Fish. Res. Bd. Canada 18: 76, Fig. 5 (record from the Hudson Bay, with illustration).

1962 Polyasterias problematica (Cleve) Meunier - Brunel, Phytoplancton de la Baie des Chaleurs: 211, P1. 66 (record from the Baie des Chaleurs, with illustration).

1991 “Dinoquiste A-B” - Martínez-Hernández and Hernández-Campos, Palaeontología Mexicana 57: 60, P1. 4, Figs, 1-4 (record from the Gulf of California, with illustration).

1997 Resting stage type C - Nehring, Bot. Mar. 40: 320, Fig. 36 (record from the German bight of the North Sea, with illustration).

1998 Hexasterias problematica Cleve - Kunz-Pirrung, Ber. Polarforsch. 281: 98, P1. 5, Fig. 3 (record form the Laptev Sea, with illustration).

1999 Polyasterias problematica (Cleve) Meunier - Bérard-Therriault et al., Guide de l'Identification: 323, P1. 149, Fig. a (record from the Gulf of Saint-Lawrence, with illustration). 
2018 Polyasterias problematica - Kubiszyn and Svensen, Bot. Mar. 61: Fig. 2 (record from the Balsafjord, Norway, with illustration).

\section{Gene sequence. [to be inserted after acceptance]}

Original diagnosis (Cleve 1900, p. 22). "Flat disk, diameter $0.04 \mathrm{~mm}$, with six, at the ends truncate and denticulate empty processes, twice as long as the radius of the disk."

Improved diagnosis. Cyst circular to subcircular outline in polar view (diameter $\sim 100 \mu \mathrm{m}$ ) and flattened in lateral view. Central cyst wall portion ("central body"; average diameter $35 \mu \mathrm{m}$ ) ornamented with four to nine radially arranged coplanar processes which are about as long as the diameter of the central body (33 $\mu \mathrm{m}$ on average). Processes hollow and empty, attached to the inner wall, show longitudinal striations, are broad at the base, open up distally and terminate in numerous ( $\sim 10$ in intact specimens) denticulations which are sometimes recurved. A central circular pylome without operculum is present when there is no cell content, but inconspicuous elsewise. Cyst wall transparent and colorless.

Studied material. Surface sediments from the Skagerrak, Baltic Sea and the Vilaine estuary (Brittany).

Description. Table 2 gives detailed morphometrics of Hexasterias problematica. The number of processes in most cases is six, but may vary from five to eight. The central body diameter and process length are correlated $\left(\mathrm{R}^{2}=0.85\right.$, Fig. 5). The cysts may be somewhat deformed from the coplanar configuration. In palynological preparations, the processes may be torn off, and the cyst is readily deformed. Cell contents include many small transparent to yellow lipid bodies (Fig. 3a-b). Micronucleus circular (3.7 $\mu \mathrm{m}$ in diameter) and macronucleus more irregular and elongated $(10.3 \times 12.7 \mu \mathrm{m})$ after DAPI staining (Fig. 6).

Remarks. Meunier (1910) reports specimens with four processes, while Bursa (1961) reports nine. In some environments, e.g., Black Sea (Verleye et al. 2009; Mudie et al. 2010), the processes are typically shorter ( $13 \mu \mathrm{m}$ in Verleye et al. 2009). Previous authors made various assumptions about the affinity of Hexasterias problematica. Hensen (1887) proposed it is a bryozoan statoblast, and 
Cleve (1900) considered it as an "unicellular alga", without any further specification. Meunier $(1910,1919)$ rejected earlier propositions of algal affinity. Erdtman (1954) proposed a phytogenous origin based in cell content. Parke and Dixon (1964, p. 529; 1968, p. 815) assigned H. problematica to the Pterospermataceae (prasinophytes); however, in Parke and Dixon (1976), it was deleted from the Pterospermataceae, and they suggested it was possibly a desmid zygote. All of these revisions and changes have led to much confusion to this day, with some authors classifying $H$. problematica as a prasinophyte (e.g., Tappan 1980, p. 818), a tintinnid cyst (e.g., Mudie et al. 2010), and others as incertae sedis (e.g., Bérard-Therriault et al. 1999). Hexasterias problematica sensu Pospelova et al. (2010, Plate VIII, fig. 7) is a desmid. Cleve (1900) referred to chromatophores with an uncertain colour; here it cannot be assessed to what he was referring to.

Occurrence and stratigraphic range. Hexasterias problematica Cleve, 1900 has been reported from both surface sediments and plankton samples. Kubiszyn and Svensen (2018) provided a distribution map for Hexasterias problematica, which is reproduced in Fig. 7 and extended with additional references from literature and personal observations. Besides the records presented by Kubiszyn and Svensen (2018), Hexasterias problematica is reliably recorded from Newfoundland (Lohmann 1904), Etang de Thau (southern France; Pavillard 1905), Nova Scotia (Wright 1907), Gullmarn Fjord (Erdtman 1954), Gulf of California (Martínez-Hernández and Hernández-Campos 1991), the German Bight of the North Sea (Nerhing 1997), the Beagle Chanel (Tierra del Fuego; Candel et al. 2012, 2013). Additional records that not substantiated by morphological data: the Faroe Islands (Ostenfeld 1903), Elbe River (Volk 1905), the west coast of Scotland (Herdman and Ridell 1911), central Atlantic Ocean (Gran 1912), Kola Gulf (Deriugin 1915), Thyborøn, (Denmark; Hansen-Ostenfeld 1916), British Coastal waters (Parke and Dixon 1964, 1968, 1976), Auray Estuary (Brittany; Paulmier 1972), southern Baltic Sea (Ringer 1973), Romanian coast of the Black Sea (Cărăuș 2002), offshore Walvis Bay (Mertens et al. 2009a), the Okhotsk Sea (Medvedeva and Nikulina 2014), Vancouver Island fjords (Gurdebeke et al. 2018). Further observations were 
made from the Vilaine Estuary (Brittany), Baltic Sea, German Wadden Sea, Harrington Sound (Bermuda Islands) and the East Chinese Sea (Mertens, Gurdebeke, unpublished data).

The cysts are resistant to chemical degradation, shown by the fact that they withstand palynological treatment using strong (hydrochloric, hydrofluoric) acids (see Material and Methods). As a fossil, $H$. problematica is mostly known from late Holocene sediments, with the oldest occurrence from Kyuquot Sound (BC, Canada), around 6.2 ka BP (P. Gurdebeke, pers. obs.). They were also found in late Holocene sediments from the Laptev Sea (Kunz-Pirrung 1998) and Saguenay Fjord (St-Onge et al. 1999), Santa Barbara Basin (Pospelova et al. 2006), the Aral Sea (Sorrel et al. 2006), Black Sea (Verleye et al., 2009; Shumilovskikh et al. 2013) and Effingham Inlet (Bringué et al. 2016).

\section{Genus Halodinium Bujak, 1984}

1984 Halodinium gen. nov.: Bujak, p. 196 (original description).

Type species. Halodinium major Bujak, 1984

Original diagnosis (Bujak, 1984). "Discoidal organic-walled microfossils with circular polar outline and irregular membranous flange. Central pylome present with lid often in place.”

Remarks. The genus Halodinium was erected by Bujak (1984), based on specimens isolated from Pleistocene North Pacific sediments. From that assemblage, he described H. major and H. minor. He considered these to be "Microphytoplankton incertae sedis". Two other species have since been described: Halodinium scopaeum by Head (1993, p. 47) and Halodinium eiriksonii by Verhoeven et al. (2014, p. 45). Halodinium was suggested to be a rhizopod by de Vernal et al. (1989) and an incertae sedis alga by Head (1993). The four species of Halodinium have been identified globally in Neogene to modern sediments. The oldest published occurrence is $H$. eiriksonii from the Zanclean (early Pliocene) of Iceland (Verhoeven et al. 2014). In the absence of molecular data and incubation experiments, the systematic positions of Halodinium and Hexasterias remained inconclusive and they were classified as acritarchs by several authors (e.g., Kunz-Pirrung 1998, p. 98). 
Species classified in Halodinium. Halodinium minor Bujak, Halodinium major Bujak, Halodinium

scopaeum Head and Halodinium eiriksonii Verhoeven et al.

Halodinium verrucatum sp. nov.

Figs. 3d-1; Fig 4, a-f; Table 3.

Diagnosis. Bilayered, polar compressed cyst with circular to subcircular (average diameter $\sim 70 \mu \mathrm{m}$ ) outline in polar view. Central body (average diameter $\sim 57 \mu \mathrm{m}$ ) ornamented with low ridges forming irregular reticulum; covered over the polar region with a thin, hyaline outer layer ornamented with discrete, bifurcating sculptural elements appearing as verrucae in LM. Near margin of central body portion, outer layer forms a wrinkled, diaphanous collar-like flange with a varying width. Central pylome with thickened rim and without operculum.

Studied material. Surface sediments from the Vilaine estuary (Brittany), the Skagerrak and the Baltic Sea.

Stratigraphical horizon and type locality. Modern sediments from the Vilaine estuary $\left(47.50^{\circ} \mathrm{N}\right.$, $2.39^{\circ} \mathrm{W}, 6 \mathrm{~m}$ water depth), Brittany (sample BV5 of Mertens et al., 2009b).

Type material. The holotype specimen, isolated from palynological residue BV5 and mounted on SEM stub 16C05 (Fig. 4, a-e), has been deposited in the collection of the National Botanic Garden of Belgium (NBGB) (accession code BR-4516).

Gene sequence. [to be inserted in proof]

Zoobank registration number of Halodinium verrucatum. [to be inserted in proof]

Etymology. The species-group name is derived from the Latin word verruca meaning wart, referring to the ornamentation as seen in light microscopy.

Description. Detailed morphometrics are given in Table 3. The holotype has a maximum central body diameter $65.0 \mu \mathrm{m}$ and a maximum diameter pylome of $12.1 \mu \mathrm{m}$; the width of its ambital flange is $11.3 \mu \mathrm{m}$. Cyst with a strong polar compression and a circular to subcircular outline in polar view (Fig. 4a-b). Cyst wall is bilayered, with the inner wall forming a central body (Fig. 2). 
Inner wall of the discoidal cyst about $1.2 \mu \mathrm{m}$ thick $(\mathrm{N}=3)$ and faintly ornamented with low ridges forming a reticulate pattern with varying mesh size $(<1 \mu \mathrm{m})$, only visible with high magnification (1000×) LM and SEM (Fig. 4d). Pylome central to the inner cyst wall, with slightly thickened rim and surrounded by a shallow circular depression of $\sim 2 \mu \mathrm{m}$ (Fig. $4 \mathrm{~d}$ ). The specimen with cell content illustrated in Fig. 3d-f, has a transparent and colorless operculum in place, but the fine structure is obscured by the cell content. Palynological specimens (e.g., Fig. 4) show no trace of an operculum. The hyaline outer layer is much thinner $(\sim 0.2 \mu \mathrm{m})$ than the inner layer and is ornamented with solid, slender sculptural elements with a widened base. With medium magnification $(400 \times$, LM), they often appear as verrucae (Fig. 3i-k) because they are recumbent (Fig. 4e), but higher LM magnifications and SEM reveal them as process-like sculptural elements. The discrete sculptural elements are of equal length (average of $1.7 \mu \mathrm{m}$, Table 3 ) and bifurcate at circa two third of their length (Fig. 4e). SEM reveals an occasional second bifurcation near the top of some sculptural elements (Fig. 4e). The sculptural elements are irregularly distributed and the distance between them averages $1.6 \mu \mathrm{m}$ (Table 3 ). The cyst outer wall layer separates from the central body near the periphery and evolves into a folded, translucent outer flange producing a coarse reticulate appearance (Fig. 4b). The delicate outer flange is often observed as torn or bent with an irregular or jagged appearance (Fig. 3h, Fig. 4a). The width of the outer flange observed on well-preserved specimens averages between $9.3 \mu \mathrm{m}$ and $25.3 \mu \mathrm{m}$ (Table 3). All observed specimens are pale and are difficult to observe under transmitted LM (Fig. 3). Sometimes, several specimens occur in clusters (Fig. 3g). Cell contents include many small transparent to yellow lipid bodies (Fig. 3d-f). Details on other organelles such as a central vacuole or the nuclear apparatus are lacking. Specimens from different studied populations are identical in all studies features.

Comparison. Halodinium verrucatum sp. nov. is distinguished from all other Halodinium species by the ornamentation of the outer wall layer (Table 4). The diameter of the central body of Halodinium major Bujak, 1984 and H. minor Bujak, 1984 are larger (104-116 $\mu \mathrm{m}$ and 46-63 $\mu \mathrm{m}$, respectively). Furthermore, their outer flange is unornamented. Halodinium scopaeum Head, 1993 
is much smaller (average diameter central body: $21-24 \mu \mathrm{m}$ ), and possesses a smooth to scabrate ornamentation. Halodinium eirikssonii Verhoeven et al., 2014 has a smaller central body (23.9-27.4 $\mu \mathrm{m})$, a rugulate outer wall layer and a complex ambital flange. Species of the genus Cyclopsiella Drugg and Loeblich, 1967 possess a more reduced ambital flange and an eccentric pylome (e.g., Matsuoka and Head 1992). Cysts of Chattonella sp., as illustrated by Mastuoka and Iishi (2018), are hemispherical and lack a flange and ornamentation.

Occurrence and stratigraphic range. Halodinium verrucatum n. sp. is described here from modern sediments in the type locality (Brittany) and the Baltic Sea, and withstands palynological treatment. This species has been recorded from modern sediments from the Skagerrak, Croatia, and Effingham Inlet (British Columbia) as well (unpublished data; see Fig. 7).

\section{Phylogenetic position of Hexasterias problematica and Halodinium verrucatum sp. nov. based on LSU rDNA and SSU rDNA}

Identical SSU rDNA (1691 bp) and partial LSU rDNA (1230 bp) sequences were obtained from three out of four specimens of Hexasterias problematica (Accession numbers: [to be inserted in proof]). For Halodinium verrucatum sp. nov., SSU rDNA (1699 bp) was obtained from a single specimen and identical LSU rDNA (1139 bp) from two specimens (Accession numbers: [to be inserted in proof]). The SSU sequences were used for phylogenetic analyses (Fig. 8), as there are more sequences available than for LSU.

In the SSU phylogeny, Hexasterias problematica formed a well-supported clade with the planktonic, marine, prostome ciliate Balanion masanensis (Fig 7; Kim et al. 2007). This clade showed a sister relationship with another clade that includes Halodinium verrucatum sp. nov. and the prostome species Urotricha sp., Plagiocampa sp. and Cryptocaryon irritans Brown (Colorni and Burgess 1997; Foissner et al. 1994, 1999; Ma et al. 2017). Both clades formed a monophyletic clade with $72 \%$ bootstrap support (Fig. 8 ). 


\section{Hexasterias and Halodinium micro-FTIR analyses}

Three specimens of Halodinium spp., three specimens of $H$. verrucatum sp. nov. and five specimens of Hexasterias problematica were measured (Fig. 9). See Table 5 for absorptions and assignments. The consistent absorption spectra for the same species from one location (e.g. the Halodinium verrucatum sp. nov. spectra from the Strö 6 station) indicates reproducibility of the method. The general consistency of spectra from one species from several locations indicates they truly reflect species composition. The remaining variation (e.g. specimen M4S13) is probably due to differing environmental conditions (cf. Bogus et al. 2014; Mertens et al. 2015; Gurdebeke et al., accepted).

Consistently strong (and often sharp, e.g., M4S28) absorptions occur at $\sim 3280 \mathrm{~cm}^{-1}(\mathrm{~N}-\mathrm{H}$ stretch), with a shoulder at $\sim 3400 \mathrm{~cm}^{-1}$ (O-H stretch) and a minor peak around $3100 \mathrm{~cm}^{-1}$. Absorptions indicative of aliphatic $\mathrm{CH}$-stretching occur in the $3000-2800 \mathrm{~cm}^{-1}$ region.

The spectral region between 1800 and $1500 \mathrm{~cm}^{-1}$ dominates in all measured spectra, with specific maxima at 1620,1570 and $1550 \mathrm{~cm}^{-1}$ and a distinct shoulder at $1640 \mathrm{~cm}^{-1}$. Nitrogencontaining (amide) group absorptions are evident in the spectra, particularly the amide I and II bands around $1600 \mathrm{~cm}^{-1}$, and minor amide III and V bands around 1312 and $690 \mathrm{~cm}^{-1}$, respectively.

The absorptions in the region between 1200 and $1000 \mathrm{~cm}^{-1}$ are indicative of $\mathrm{C}-\mathrm{O}-\mathrm{C}$ asymmetric vibration $\left(\sim 1160 \mathrm{~cm}^{-1}\right)$, glucose ring stretch $\left(\sim 1110 \mathrm{~cm}^{-1}\right)$ and C-O stretching $(\sim 1040$ $\left.\mathrm{cm}^{-1}\right)$. They are indicative of polysaccharides but lacking diagnostic absorptions of $\beta$-linkage around $900 \mathrm{~cm}^{-1}$ (Cárdenas et al. 2004; Kačuráková et al. 2002).

There is variability in the composition of Halodinium spp. specimens (Fig. 9), in that several of the specimens showed relatively weak absorptions for C-O bonds, and the position of the strongest peak was either $1620 \mathrm{~cm}^{-1}$ (Halodinium sp. from the Irish Sea and Brittany) or $1570 \mathrm{~cm}^{-1}$ (H. verrucatum sp. nov. from the Skagerrak). These compositional differences may reflect interspecific or environmental differences. In earlier studies most Halodinium specimens from Brittany and the Irish Sea were found to be H. minor. The Hexasterias problematica spectra also 
show variability in the relative strength of the absorptions, specifically the specimen (M4S13) where the absorptions from 1160 to $1040 \mathrm{~cm}^{-1}$ are stronger than in the others.

The absorption spectra recorded for the tintinnid loricae (Parafavella sp. and Stenosemella sp.) are very similar to Hexasterias and Halodinium. The two spectra of Parafavella sp. specimens from Skagerrak are more or less identical (Fig. 10); the spectrum of Stenosemella sp. differs in having more pronounced shoulders at $1640 \mathrm{~cm}^{-1}$ and $1550 \mathrm{~cm}^{-1}$, and there are some differences in the spectral region around $1400 \mathrm{~cm}^{-1}$.

Radiosperma corbiferum cysts (Fig. 10) again show similarities with Hexasterias and Halodinium, with maximal absorptions at 1620 or $1570 \mathrm{~cm}^{-1}$ and a similar shape in the region around $1400 \mathrm{~cm}^{-1}$. There are some differences, however, for instance there is an additional small absorption around $3440 \mathrm{~cm}^{-1}$ and relatively stronger absorptions in the region $1040-1160 \mathrm{~cm}^{-1}$, especially at $1040 \mathrm{~cm}^{-1}$.

\section{Discussion}

\section{Phylogenetic implications and relation to acritarchs}

The rDNA sequences extracted from Hexasterias problematica and Halodinium verrucatum sp. nov. reveal a phylogenetic placement within the ciliate order Prorodontida (Gao et al. 2016). The genealogical structure and monophyly of the Colepidae, Prorodontidae, and Placidae (see Fig. 8) is in agreement with earlier studies (Gao et al. 2016; Lipscomb et al. 2012; Mordret et al. 2016; Zhang et al. 2014). The placement with the ciliates is further supported for Hexasterias problematica by the DAPI-staining, which shows a dual nuclear apparatus (Fig. 6), a derived character of the ciliates. This is in line with earlier observations of ciliate nuclei with DAPI staining (e.g., Bellec et al. 2014). Further observations of nuclear dualism should be made with the classic approach using TEM (e.g., Grimes 1973).

In this data set, Hexasterias problematica is most closely related to Balanion masanensis, described by Kim et al. (2007) from coastal waters off South Korea. Halodinium verrucatum sp. 
nov. is most closely related to the freshwater Urotricha sp. (EU024981) with which it forms a sister clade to Plagiocampa sp. and the fish parasite Cryptocaryon irritans, both marine species (Wright and Colorni 2002; Zhang et al. 2014). The clade formed by these has been reported previously (Zhang et al. 2014), but the nature of the relationship with the Class Plagiopylea remains unclear (Gao et al. 2016).

Within the free-living Ciliophora, the formation of resting cysts is common (see reviews in Guttiérez et al. 2001 and Verni and Rosati 2011), but detailed information on morphology and physiology is only known for a very limited number of species (Verni and Rosati 2011). Most welldescribed palynologically preservable cysts are assigned to the class Spirotrichea (Reid and John 1978, 1983). For the class Prostomatea, cysts have been described for Prorodon (Hiller and Bardele 1988) and Cryptocaryon irritans (Ma et al. 2017).

It is hypothesized that the palynomorphs Hexasterias problematica and Halodinium verrucatum sp. nov. represent cryptobiotic cyst stages of prorodontid ciliates. The classification of the Order Prorodontida is based on characteristics not present in cyst stages, such as the nature of the cytostome, kinetids and the brosse (Lynn 2008), and life cycle stages of a single species can be significantly heteromorphic (Hiller and Bardele 1988). Thus far, there are no morphological observations of the ciliates that supposedly produce the cysts Hexasterias problematica and Halodinium verrucatum sp. nov., and consequently the placement of these species within the order Prorodontida cannot be evaluated in light of diagnostic characteristics of their planktonic stages. Incubation experiments, which have been unsuccessful to date, or increased molecular taxon sampling could provide further insights. This situation stresses the importance of including cyst morphology in future ciliate species descriptions.

The average size of Halodinium verrucatum and Hexasterias problematicum is within the range of other known ciliate cysts (see Table II in Verni and Rosati 2011). The disk-shaped morphology, however, is unusual for ciliate cysts, which are typically globular or flask-shaped. This suggests that the morphological disparity within ciliate cysts might be larger than expected. The 
double cyst wall texture of Halodinium verrucatum sp. nov. agrees with the observation that ciliate cyst walls in general differentiate between a thick inner and a thinner outer cyst wall (Matsusaka et al. 1989; Verni and Rosati 2011). TEM would be needed to evaluate the ultrastructure of the inner cyst wall, which in many cases is multi-layered in ciliate cysts (Verni and Rosati 2011).

It is expected that morphologically similar, two-layered marine acritarchs with a pylome, such as the other Halodinium species, Radiosperma corbiferum, and Cyclopsiella (e.g. Matsuoka and Head 1992) may also be affiliated with the ciliates. An affinity with the ciliates has also been tentatively proposed for other acritarchs with pylomes, such as species of Palaeostomocystis (Roncaglia 2004; Warny et al. 2009). It should be noted, however, that other organic microfossils with a circular opening exist (e.g., testate amoeba, desmids, cysts of the raphidophycean Chattonella), but these differ in structure, composition and autecology. For many extinct acritarch species with a pylome structure, described from older sediments, a ciliate affinity may be considered, e.g. the Proterozoic Appendisphaera (Moczydłowska et al. 2011) or the Ordovician Velatasphaera (e.g., Miller and Williams 1988). However, because of the impossibility of obtaining molecular data for these species, combined observations of detailed morphology, wall structure, chemical composition and paleoecology would be needed to support this affiliation (Aroui et al. 1999; Marshall et al. 2005).

\section{Distribution and ecology of Hexasterias problematica and Halodinium verrucatum sp. nov.}

Specimens of Hexasterias problematica are typically recovered from plankton and surface sediments in estuarine and coastal areas in temperate zones of the northern and southern hemisphere (Fig. 7). Occurrences range from fresh to fully marine waters. Mudie (1992) linked the abundances in surface sediments with river/meltwater input. Indeed, sediment trap studies in British Columbia found a positive relationship between $H$. problematica abundance and freshwater input (Pospelova et al. 2010; Price and Pospelova 2011). Consequently, H. problematica has been used as an indicator for freshwater input in paleoecological studies (e.g., Bringué et al. 2016). In all, it seems 
that $H$. problematica is a euryhaline species, occurring from fresh to marine environments, but with maximal abundances in the case of lowered salinities (brackish water) due to freshwater discharge. The short (average of $16.2 \mu \mathrm{m}, \mathrm{n}=4$ in Verleye et al. 2009) processes noted for specimens from the Black Sea (e.g., Verleye et al. 2009; Mudie et al. 2010) suggest a possible covariance of process length with environmental variables such as salinity. Similar relationships were noted for dinoflagellate cyst species Lingulodinium machaerophorum (Mertens et al. 2009b; Verleye et al. 2009) and Operculodinium centrocarpum (Mertens et al. 2011) and allow application of these microfossils as a proxy for paleoenvironmental conditions (e.g., Mertens et al. 2012b; Bringué et al. 2016). The relation should be explored quantitatively for Hexasterias problematica.

For Halodinium, many authors do not distinguish species, preventing definite statements about the distributions of individual species. The sparse occurrence data of Halodinium verrucatum sp. nov. suggests it occurs in coastal estuarine environments with brackish marine salinities (Aure et al. 1993; Arapov et al. 2017). A similar ecology is often assigned to "Halodinium sp." in palynological studies (e.g. Matthiessen 1995) and to Halodinium minor in the sediment trap study of Price and Pospelova (2011).

In the light of their phylogenetic position (Fig. 8), both Hexasterias and Halodinium are grouped in a clade with mainly marine species, except for Urotricha sp., that is most closely related to Halodinium verrucatum sp. nov. and was sequenced from lacustrine plankton (Auinger et al. 2008). This large genus includes mostly freshwater but also marine species (e.g., Foissner et al. 1999; Wilbert and Song 2008).

The irregular flange rim and the monospecific clusters of specimens of Halodinium verrucatum sp. nov. (Fig. 3g) are not unlike the morphology described by Matsuoka and Head (1992) for Cyclopsiella, suggesting an attached, perhaps encrusting mode of life.

\section{Geochemical composition}


The measured spectra bear some similarity to a carbohydrate-based macromolecule described from heterotrophic dinoflagellates (Bogus et al. 2014; Mertens et al. 2015), e.g., the abundant sugar group component, specifically in Halodinium spp. from Brittany and the Irish Sea, and the amide functional groups. There are significant differences, however, suggesting that the composition here is not dinosporin. In particular, strong $\mathrm{C}-\mathrm{O}$ bonds and evidence for a $\beta$-glycosidic linkage are lacking. The spectra also differ from chitin (Cárdenas et al. 2004), which was the cyst composition found by e.g. Foissner et al. (2005) and Verni and Rosati (2011) using a Van Wesselingh test. This evidence supports the rejection by Agatha and Simon (2012) for a chitinous composition of ciliate loricae and cysts.

The spectra of the loricae of the tintinnids Parafavella sp. and Stenosemella sp. indicate a comparable composition and corroborate the results of Agatha and Simon (2012), who evaluated tintinnid loricae using a multitude of methods, and suggested a nitrogen-rich proteinaceous composition. These authors also found, however, that polysaccharides are never the main component of tintinnid loricae.

The compositional similarity of Halodinium verrucatum and Hexasterias problematica with the loricae supports their placement in the ciliates revealed by the genetic data. The scarce reports on ciliate cyst wall chemistry (Izquierdo et al. 2000; Wang et al. 2017) report a composition of mainly carbohydrates and (glyco)proteins. Wang et al. (2017) found, using electrophoresis combined with ionization mass spectrometry, that the protein composition within a single species is very diverse (42 proteins), a resolution that cannot be achieved by single specimen micro-FTIR.

The chemical composition of both Hexasterias and Halodinium indicates that they are formed by heterotrophic organisms, evidenced by amide groups in the wall chemistry (see Table 5), a result also found for cysts of heterotrophic dinoflagellates (Bogus et al. 2014). This is also in accordance with their placement with the ciliates, which are nearly all heterotrophic (Lynn 2008). This illustrates that cyst wall chemistry is a more reliable indicator for trophic preference of the 
producing organism than are cyst color and autofluorescence, the approaches often applied with dinoflagellate cysts (Brenner and Biebow 2001; Bogus et al. 2014).

Finally, the acritarch Radiosperma corbiferum shows a similar composition, which would further support a ciliate affinity of acritarchs with a similar morphology, although genetic data is needed to confirm this. These results complement earlier studies applying spectroscopical techniques to fossil acritarchs to test hypotheses about their affinity (e.g., Arouri et al. 2000; Dhamelincourt et al. 2010).

\section{Conclusions}

Two palynomorphs, Hexasterias problematica, and a new species of the genus Halodinium, $H$. verrucatum sp. nov., were retrieved from surface sediments from Brittany, the Skagerrak and the Baltic Sea. Phylogenetic analysis using rDNA (LSU and SSU) revealed that these species belong to the ciliates (phylum Ciliophora), more specifically within the order Prorodontida. The ciliate nature is supported by the presence of a micro- and macronucleus. Both species represent cryptobiotic cyst stages of hitherto undescribed ciliate species.

This placement is supported by the cyst wall chemistry, which, evaluated using micro-FTIR, is found similar to that of loricae of the tintinnid ciliates Stenosemella sp. and Parafavella sp. The cyst wall is carbohydrate-based and contains nitrogen-containing functional groups. The composition is in accordance with the heterotrophic nature of the ciliates.

Hexasterias problematica and species of Halodinium have a global distribution, mainly in temperate coastal waters, and are often encountered in palynological studies. The affinity with the ciliates provides a better understanding of their ecological significance as an indicator for coastal conditions and freshwater influence.

Finally, the results of this study highlight the potential utility of micro-FTIR in understanding acritarch affinity, especially for fossil taxa for which molecular data are unavailable. As a test case, an acritarch with a similar morphology, here represented by Radiosperma 
corbiferum, was found to have a similar composition and possibly has a similar affinity, which should be confirmed by molecular data.

\section{Acknowledgements}

Veijo Kinnunen and Magnus Lindstrom are thanked for assistance with sampling Sällvik. Jaana Koistinen is thanked for help with shipping samples from Finland to Japan. Anna Godhe is thanked for providing surface sediment from the Skagerrak. Sabine Agatha is acknowledged for help with identifications of tintinnid loricae. Zivana Nincevic is thanked for information about the sample from Kastela Bay.

Funding: This work was supported by the Hercules Foundation (FWO, Flanders) [FT-IMAGER project - AUGE/13/16] and the National Science Foundation [OCE - 1326927].

\section{References}

Agatha, S., Simon, P., 2012. On the nature of the tintinnid loricae (Ciliophora: Spirotricha: Tintinnina): A histochemical, enzymatic, EDX, and high-resolution TEM study. Acta Protozool. 51, 1-19.

Arapov, J., Skejić, S., Bužančić, M. Bakrač, A., Vidjak, O., Bojanić, N., Ujević, I., Živana N. Gladan, Ž.N., 2017. Taxonomical diversity of Pseudo-nitzschia from the Central Adriatic Sea. Phycol. Res. 65, 280-290.

Aroui, K., Greenwood, P.F., Walter, M.R., 1999. A possible chlorophycean affinity of some Neoproterozoic acritarchs. Org. Geochem. 30, 1323-1337.

Auinger, B.M., Pfandl, K., Boenigk, J., 2008. Improved methodology for identification of protists and microalgae from plankton samples preserved in Lugol's iodine solution: Combining microscopic analysis with single-cell PCR. Appl. Environ. Microbiol. 74, 2505-2510.

Aure, J., Føyn, L., Pettersen, R., 1993. Environmental monitoring of Norwegian fjord 1975-1993. Fisken of Havet 12, 35 pp. 
Bellec, L., Maurer-Alcale, X.X., Kats, L.A., 2014. Characterization of the life cycle and heteromeric nature of the macronucleus of the ciliate Chilodonella uncinata using fluorescence microscopy. J. Eukaryot. Microbiol. 61, 313-316.

Bérard-Therriault, L., Poulin, M., Bossé, L., 1999. Guide d'identification du phytoplancton marin de l'estuaire et du golfe du Saint-Laurent incluant également certains protozoaires. Can. Spec. Publ. of Fish. Aquat. Sci. 128, 1-387.

Bogus, K., Mertens, K.N., Lauwaert, J., Harding, I.C., Vrielinck, H., Zonneveld, K.A.F., Versteegh, G.J.M., 2014. Differences in the chemical composition of organic-walled dinoflagellate resting cysts from phototrophic and heterotrophic dinoflagellates. J. Phycol. 50, 254-266.

Bolch, C.J.S., 1997. The use of polytungstate for the separation and concentration of living dinoflagellate cysts from marine sediments. Phycologia 37, 472-478.

Brenner, W.W., Biebow, N., 2001. Missing autofluorescence of recent and fossil dinoflagellate cysts - an indicator of heterotrophy? N. Jb. Geol. Paläont. Abh. 219, 229-240.

Bringué, M., Pospelova, V., Calvert, S.E., Enkin, R.J., Lacourse, T., Ivanochko, T., 2016. High resolution dinoflagellate cyst record of environmental change in Effingham Inlet (British Columbia, Canada) over the last millennium. Palaeogeogr., Palaeoclimatol., Palaeoecol. 441, $787-810$.

Bruker, 2014. OPUS Spectroscopy Software User Manual. Bruker Optik GmbH, Ettlingen.

Brunel, J., 1962. Le phytoplancton de la Baie des Chaleurs. Contributions 91 du Ministere de la Chasse et des Pecheries, Montréal. pp. 365.

Bujak, J.P., 1984. Cenozoic dinoflagellate cysts and acritarchs from the Bering Sea and northern North Pacific, DSDP Leg 19. Micropaleontology 30, 180-212.

Bursa, A., 1961. Phytoplankton of the Calanus expeditions in Hudson Bay, 1953 and 1954. J. Fish. Res. Bd. Canada 18, 51-83. 
Candel, M.S., Radi, T., de Vernal, A., Bujalesky, G., 2012. Distribution of dinoflagellate cysts and other aquatic palynomorphs in surface sediments from the Beagle Channel, Southern Argentina. Mar. Micropaleontol. 96-97, 1-12.

Candel, M.S., Borromei, A.M., Martinez, M.A., Bujalesky, G., 2013. Palynofacies analysis of surface sediments from the Beagle Channel and its application as modern analogues for Holocene records of Tierra del Fuego, Argentina. Palynology 37, 62-76.

Cărăuş, I., 2002. Algae of Romania - A distributional checklist of actual algae. Studii şi Cercetări, 7, $694 \mathrm{pp}$.

Cárdenas, G., Cabrera, G., Taboada, E., Miranda, S.P., 2004. Chitin characterization by SEM, FTIR, XRD, and ${ }^{13} \mathrm{C}$ cross polarization/mass angle spinning NMR. J. Appl. Polym. Sci. 93, $1876-1885$.

Cleve, P.T., 1900. The plankton of the North Sea, the English Channel, and the Skaggerrak in 1898. K. Sven. Vetenskapsakad. Handl. 32, 2-53.

Colbath, G.K., Grenfell, H.R., 1995. Review of biological affinities of Paleozoic acid-resistant, organic walled eukaryotic algal microfossils (including "acritarchs”). Rev. Paleobot. Palynol. $86,287-314$

Colorni, A., Burgess, P., 1997. Cryptocaryon irritans Brown 1951, the cause of 'white spot disease' in marine fish: An update. Aquar. Sci. Cons. 1, 217-238.

Colthup, N.B., Daly, L.H., Wiberley, S.E., 1990. Introduction to Infrared and Raman Spectroscopy, $3^{\text {rd }}$ ed., Academic Press, San Diego, 547 pp.

Dale, B., 1977. New observation on Peridinium faroense Paulsen (1905), and classification of small orthoperidinioid dinoflagellates. British Phycol. J. 12, 241-253.

Darriba, D., Taboada, G.L., Doallo, R., Posada, D., 2012. jModelTest 2: more models, new heuristics and parallel computing. Nat. Methods 9, 772. 
de Vernal., A., Goyette, C., Rodrigues, C.G., 1989. Contribution palynostratrigraphique (dinokystes, pollen et spores) à la connaissance de la mer Champlain: Coupe de Saint-Césaire, Québec. Can. J. Earth Sci. 26, 2450-2464.

Deriugin, K.M., 1915. La Faune du Golfe de Kola et les conditions de son existence. Mémoires de l’Académie Imperiale des Sciences de Petrograd 34.

Dhamelincourt, M.-C., Vecoli, M., Mezzetti, A., Cesari, C. Versteegh, G., Riboulleau, A., 2010. Laser Raman micro-spectroscopy of Proterozoic and Palaeozoic organic-walled microfossils (acritarchs and prasinophytes) from the Ghadamis Basin, Libya and Volta Basin, Ghana. Spectroscopy 24, 207-212.

Dolan, J.R., Montagnes, D.J.S., Agatha, S., Coats, D.W., Stoecker, D.K., 2013. The Biology and Ecology of Tintinnid Ciliates. Wiley-Blackwell, 296 pp.

Dunthorn, M., Otto, J., Berger, S.A., Stamatakis, A., Mahé, F., Romac, S., de Vargas, C., Audic, S. et al., 2014. Placing environmental next-generation sequencing amplicons from microbial eukaryotes into a phylogenetic context. Mol. Biol. Evol. 31, 993-1009.

Dunthorn, M., Lipps, J.H., Dolan, J.R., Saab, M.A., Aescht, E., Bachy, C., Barría de Cao, M.S., Berger, H. et al., 2015. Ciliates - Protists with complex morphologies and ambiguous early fossil record. Mar. Micropaleontol. 119, 1-6.

Erdtman, G., 1954. On pollen grains and dinoflagellate cysts in the Firth of Gullmarn, SW Sweden. Bot. Not. 2, 103-111.

Evitt, W.R., 1963. A discussion and proposals concerning fossil dinoflagellates, hystrichospheres, and acritarchs, II. Proc. Natl. Acad. Sci. U. S. A. 49, 298-302.

Foissner, W., Berger, H., Kohmann, F., 1994. Taxonomische und ökologische Revision der Ciliaten des Saprobiensystems, Band III: Hymenostomata, Prostomatida, Nassulida. Informationsberichte des Bayer. Landesamtes für Wasserwirtschaft, 1/94: 1-548.

Foissner, W., Herger, H., Schaumburg, J., 1999. Identification and Ecology of Limnetic Plankton Ciliates. Bavarian State Office for Water Management Reports, Issue 3/99, 793 pp. 
Foissner, W., Müller, H., Weisse, T., 2005. The unusual, lepidosome-coated resting cyst of Meres corlissi (Ciliophora : Oligotrichea) : Light and scanning electron microscopy, cytochemistry. Acta Protozool. 44, 201-2015.

Foissner, W., Chao, A., Katz, L.A., 2008. Diversity and geographic distribution of ciliates (Protista: Ciliophora). Biodivers. Conserv. 17, 345-363.

Gao, F., Warren, A., Zhang, Q., Gong, J., Miao, M., Sun, P., Xu, D., Huang, J., Yi, Z., Song, W., 2016. The all-data-based evolutionary hypothesis of ciliated protists with a revised classification of the Phylum Ciliophora (Eukaryota, Alveolata). Sci. Rep. 6, 24874.

Gran, H.H., 1912. Pelagic plant life. In: Murray, J.J., Hjort, J., The Depth of the Ocean. McMillan, London, 307-386.

Grimes, G.W., 1973. Differentiation during encystment and excystment in Oxytricha fallax. J. Protozool. 20, 92-104.

Guindon, S., Gascuel, O., 2003. A simple, fast, accurate algorithm to estimate large phylogenies by maximum likelihood. Syst. Biol. 52, 696-704.

Gurdebeke, P.R., Mertens, K.N., Bogus, K., Marret, F., Chomérat, N., Vrielinck, H., Louwye, S. (accepted). Taxonomic re-investigation and geochemical characterization of Reid's (1974) species of Spiniferites from holotype and topotype material. Palynology. DOI:10.1080/01916122.2018.1465735

Gurdebeke, P.R., Pospelova, V., Mertens, K.N., Chana, J., Louwye, S., 2018. Diversity and distribution of dinoflagellate cysts in surface sediments from fjords of western Vancouver Island (British Columbia, Canada). Mar. Micropaleontol. 143, 12-29..

Guttiérez, J.C., Callejas, S., Borniquel, S., Benítez, L., Martín-Gonzalez, A., 2001. Ciliate cryptobiosis: a microbial strategy against environmental starvation. Int. Microbiol. 4, 151157.

Hansen-Ostenfeld, C. 1916. De Danske Farvandes Plankton i aarene 1898-1901, phytoplankton og protozooer. Kgl. danske Vidensk. Selsk, 2, 298-378. 
Head, M. J., 1993. Dinoflagellates, sporomorphs, and other palynomorphs from the upper Pliocene St. Earth beds of Cornwall, southwestern England. The Palaeontological Society Memoirs 31, $62 \mathrm{pp}$.

Heiskanen, A.-S., Tallberg, P., 1999. Sedimentation and particulate nutrient dynamics along a coastal gradient from a fjord-like bay to the open sea. Hydrobiologia 393, 127-140.

Hensen, V., 1887. Ueber die Bestimmung des Plankton's oder des im Meere treibende Materials an Pflanzen und Tieren. Fünfter Bericht der Kommission zur wissenschaftlichen Untersuchung der deutschen Meere in Kiel für die Jahre 1882 bis 1886, 12-16, pp. 1-107.

Herdman, W.A., Ridell, W., 1911. Plankton of the West Coast of Scotland in relation to that of the Irish Sea. Proc. Trans. Liverpool Biol. Soc. 25, 132-185.

Hiller, S., Bardele, C.F., 1988. Prorodon aklitolophon n. spec. and the "Dorsal Brush" as a character to identify certain subgroups in the genus Prorodon. Arch. Protistenkd. 136, $213-$ 236.

Izquierdo, A., Martín-González, A., Guttiérez, J.C., 2000. Resting cyst wall glycoproteins isolated from two colpodid ciliates are glycine-rich proteins. Cell Biol. Int. 24, 115-119.

Javaux, E.J., Marshall, C.P., 2006. A new approach in deciphering early protist paleobiology and evolution: Combined microscopy and microchemistry of single Proterozoic acritarchs. Rev. Palaeobot. Palynol. 139, 1-15.

Kačuráková, M., Smith, A.C., Gidley, M.J., Wilson, R.H., 2002. Molecular interactions in bacterial cellulose composites studied by 1D FT-IR and dynamic 2D FT-IR spectroscopy. Carbohydr. Res. 337, 1145-1153.

Kapuscinski, J., 1995. DAPI: A DNA-specific fluorescent probe. Biotech. Histochem. 70, 220-233.

Kaźmierczak, J., Kremer, B., 1999. Spore-like bodies in some early Paleozoic acritarchs: Clues to chlorococcalean affinities. Acta Paleontol. Pol. 54, 541-551. 
Kim, J.S., Jeong, H.J., Lynn, D.E., Park, J.Y., Lim, Y.W., Shin, W., 2007. Balanion masanensis n. sp. (Ciliophora: Prostomatea) from the Coastal Waters of Korea: Morphology and Small Subunit Ribosomal RNA Gene Sequence. J. Eukaryot. Microbiol. 54, 482-494.

Kubiszyn, A.M., Svensen, C., 2018. First record of a rare species, Polyasterias problematica (Prasinophyceae), in Balsafjord, northern Norway. Bot. Mar. 61, 421-428.

Kunz-Pirrung, M., 1998. Aquatic palynomorphs: Reconstruction of Holocene sea-surface water masses in the eastern Laptev Sea. Ber. Polarfosch. 281, 1-117.

Lipscomb, D.L., Bowditch, B.M., Riordan, G.P., 2012. A molecular and ultrastructural description of Spathidiopsis buddenbrocki and the phylogenetic position of the family Placidae (Ciliophora). J. Eukaryot. Microbiol. 59, 67-79.

Lohmann, H., 1904 Ergebnisse der Plankton-Expedition der Humboldt-Stiftung. Band IV, p. 32.

Lynn, D.H., 2008. The Ciliated Protozoa. Characterization, Classification, and Guide to the Literature, $3^{\text {rd }}$ edition. Springer, $605 \mathrm{pp}$.

Ma, R., Fan, X., Yin, F., Ni, B., Gu, F., 2017. Ultrastructural features of the tomont of Cryptocaryon irritans (Ciliophora: Prostomatea), a parasitic ciliate of marine fishes. Parasitology 144, 720-729.

Marshall, C.P., Javaux, E.J. Knoll, A.W., Walter, M.R., 2005. Combined micro-Fourier transform infrared (FTIR) spectroscopy and micro-Raman spectroscopy of Proterozoic acritarchs: A new approach to Palaeobiology. Prec. Res. 138, 208-224.

Martínez-Hernández, E., Hernández-Campos, H.E., 1991. Distribution des quistes de dinoflagelados y acritarchas en sedimentos Holocenicos del Golfo de California. Palaeontología Mexicana 57, 133 pp.

Matsuoka, K., Head, M.J., 1992. Taxonomic revision of the Neogene marine palynomorphs Cyclopsiella granosa (Matsuoka) and Batiacasphaera minuta (Matsuoka), and a new species of Pyxidinopsis Habib (Dinophyceae) from the Miocene of the Labrador Sea. In. Head, M. J. 
Matsuoka, K., Iishi, K., 2018. Marine and freshwater palynomorphs preserved in surface sediments of Osaka Bay, Japan. Bull. Osaka Mus. Nat. Hist. 72, 1-17.

Matsusaka, T., Noguchi, O., Yonezawa, F., 1989. Cortical morphogenesis during encystment in a ciliate, Euplotes encysticus Yonezawa 1985. Europ. J. Protistol. 24, 133-137.

Matthiessen, J., 1995. Distribution patterns of dinoflagellate cysts and other organic-walled microfossils in recent Norwegian-Greenland Sea sediments. Mar. Micropaleontol. 24, 307334.

McMinn, A., Bolch, C., Hallegraeff, G., 1992. Cobricosphaeridium Harland and Sarjaent: Dinoflagellate cyst or copepod egg? Micropaleontology 38, 315-316.

Medvedeva, L.A., Nikulina, T.V., 2014. Catalogue of freshwater algae of the southern part of the Russian Far East. Vladivostok: Dalnauka, 271 p.

Mertens, K.N., Verhoeven, K., Verleye, T., Louwye, S., Amorim, A., Ribeiro, S., Deaf, A.S., Harding, I.C. et al., 2009a. Determining the absolute abundance of dinoflagellate cysts in recent marine sediments: The Lycopodium marker-grain method put to the test. Rev. Palaeobot. Palynol., 157, 238-252.

Mertens, K.N., Ribeiro, S., Bouimetarhan, I., Caner, H., Nebout, N.C., Dale, B., de Vernal, A., Ellegaard, M. et al., 2009b. Process length variation in cysts of a dinoflagellate, Lingulodinium machaerophorum, in surface sediments: Investigating its potential as salinity proxy. Mar. Micropaleontol. 70, 54-69.

Mertens, K.N., Dale, B., Ellegaard, M., Jansson, I.-M., Godhe, A., Kremp, A., Louwye, S., 2011. Process length variation in cysts of the dinoflagellate Protoceratium reticulatum, from surface sediments of the Baltic-Kattegat-Skagerrak estuarine system: a regional salinity proxy. Boreas 40, 242-255. 
Mertens, K.N., Bringué, M., Van Nieuwenhove, N., Takano, Y., Pospelova, V., Rochon, A., de Vernal; A., Radi, T. et al., 2012a. Process length variation of the cyst of the dinoflagellate Protoceratium reticulatum in the North Pacific and Baltic-Skagerrak region: calibration as an annual density proxy and first evidence of pseudo-cryptic speciation. J. Quaternary Sci. 27, 734-744.

Mertens, K.N., Bradley, L.R., Takano, Y., Mudie, P.J., Marret, F., Aksu, A. E., Hiscott, R.N., Verleye, T.J. et al., 2012b. Quantitative estimation of Holocene surface salinity variation in the Black Sea using dinoflagellate cyst process length. Quat. Sci. Rev. 39, 45-59.

Mertens, K.N., Wolny, J., Carbonell-Moore, C., Bogus, K., Ellegaard, M., Limoges, A., de Vernal, A., Gurdebeke P.R. et al., 2015. Taxonomic re-examination of the toxic armored dinoflagellate Pyrodinium bahamense Plate 1906: Can morphology or LSU sequencing separate P. bahamense var. compressum from var. bahamense? Harmful Algae 41, 1-24.

Mertens, K.N., Gu, H., Pospelova, V., Chomérat, N., Nézan, E., Gurdebeke, P.R., Bogus, K., Vrielinck, H. et al., 2017. First record of resting cysts of the benthic dinoflagellate Prorocentrum leve in a natural reservoir in Gujan-Mestras, Gironde, France. J. Phycol. 53, $1193-1205$.

Meunier, A., 1910. Microplankton des Mers de Barents et de Kara. Duc d'Orléans. Campagne arctique de 1907. Imprimerie scientifique Charles Bulens: Bruxelles. 355 pp. + atlas (XXXVII plates).

Meunier, A., 1919. Microplankton de la mer Flamande. Mém. Mus. Hist. Nat. Belgique, 8, 59 pp..

Miller, M.A., Williams, G. L., 1988. Velatasphaera hudsonii gen. nov. et sp. nov., an Ordovician acritarch from Hudson Strain, North West Territories, Canada. Palynology 12, 121-127.

Moczydłowska, M., Landing, E., Zang, W., Palacios, T., 2011. Proterozoic phytoplankton and timing of chlorophyte algae origins. Palaeontology 54, 721-733. 
Mordret, S., Romac, S., Henry, N., Colin, S., Carmichael, M., Berney, C., Audic, S., Richter, D.J. et al., 2016a. The symbiotic life of Symbiodinium in the open ocean within a new species of calcifying ciliata (Tiarina sp.). ISME J. 10, 1424-1436.

Mudie, P.J., 1992. Circum-arctic Quatematy and Neogene marine palynofloras: paleoecology and statistical analysis. M.J. Head, J.H. Wrenn (Editors), Neogene and Quatemary Dinoflagellate Cysts and Acritarchs. Am. Assoc. Stratigr. Palynol. Found., Dallas, pp. 347-390.

Mudie, P.J., Marret, F., Rochon A., Aksu, A.E., 2010. Non-pollen palynomorphs in Black Sea corridor. Veget. Hist. Archaeobot. 19, 531-544.

Nehring, S., 1997. Dinoflagellate resting cysts from Recent German coastal sediments. Bot. Mar., 40, 307-324.

Ostenfeld, C.H., 1903. Phytoplankton from the sea around the Faröes. In Botany of the Faroës, based upon Danish investigations, part II, pp.558-612.

Parke, M., Dixon, P.S., 1964. A revised check-list of British marine algae. J. mar. Biol. Ass. U.K. 44, 499-542.

Parke, M., Dixon, P.S., 1968. A revised check-list of British marine algae - Second revision. J. mar. Biol. Ass. U.K. 48, 783-832.

Parke, M., Dixon, P.S., 1976. Check-list of British marine algae - Third revision. J. mar. Biol. Ass. U.K. 56, 527-594.

Paulmier, G., 1972. Seston - phytoplankton et microphytobenthos en rivière d'Auray. Leur role dans le cycle biologique des huîtres (Ostrea edulis L.). Thèse de Doctorat de l’Université de Provence, $142 \mathrm{pp}$.

Pavillard, J., 1905. Recherches sur la flore pélagique (phytoplankton) de l'Étang de Thau, Impr. G. Firmin, Montane et Sicardi, 1905, 116 p.

Penn, O., Privman, E., Ashkenazy, H., Landan, G., Graur, D., Pupko, T., 2010a. GUIDANCE: a web server for asessing alignment confidence scores. Nucleic Acids Res. 38, W23-W28. 
Penn, O., Privman, E., Landan, G., Graur, D. and Pupko, T., 2010b. An alignment confidence score capturing robustness to guide tree uncertainty. Mol. Bio. Evol. 27, 1759-1767.

Pospelova, V., Pedersen, T.F., de Vernal, A., 2006. Dinoflagellate cysts as indicators of climatic and oceanographic changes during the past $40 \mathrm{kyr}$ in the Santa Barbara Basin, southern California. Paleoceanography 21, 16 pp.

Popselova, V., Esenkulva, S., Johannessen, S.C., O’Brien, M.C., Macdonald, R.W., 2010. Organicwalled dinoflagellate cyst production, composition and flux from 1996 to 1998 in the central Strait of Georgia (BC, Canada): A sediment trap study. Mar. Micropaleontol. 75, 17-37.

Price, A.M., Pospelova, V., 2011. High-resolution sediment trap study of organic-walled dinoflagellate cyst production and biogenic silica flux in Saanich Inlet (BC, Canada). Mar. Micropaleontol. 80, 18-43.

Reid, P.C., John, A.W. G., 1978. Tintinnid cysts. J. mar. Biol. Ass. U.K. 58, 551-557.

Reid, P.C., John, A.W.G., 1983. Resting cysts in the Ciliate class Polyhymenophorea : Phylogenetic implications. J. Protozool. 30, 710-713.

Ringer, Z., 1973. Phytoplankton of the southern Baltic Sea. Pol. Arch. Hydrobiol. 20, 371-378.

Roncaglia, L., 2004. New acritarch species from Holocene sediments in central West Greenland. Grana 43, 81-88.

Servais, T., 1996. Some considerations on acritarch classification. Rev. Palaeobot. Palynol. 93, 922.

Shumilovskikh, L.S., Marret, F., Fleitmann, D., Arz, H.W., Nowaczyk, N. Behling, H., 2013. Eemian and Holocene sea-surface conditions in the southern Black Sea: Organic-walled dinoflagellate cyst record from core 22-GC3. Mar. Micropaleontol. 101, 146-160.

Sorrel, P., Popescu, S.-M., Head, M.J., Suc, J.P. Klotz, S., Oberhänsli, H., 2006. Hydrographic development of the Aral Sea during the last 2000 years based on quantitative analysis of dinoflagellate cysts. Palaeongeogr., Palaeoclimatol., Palaeoecol. 234, 304-327. 
Stamatakis, A., Hoover, P., Rougemont, J., 2008. A fast boostrap algorithm for the RAxML webservers. Syst. Biol. 57, 758-771

St-Onge, G., Leduc, J., Bilodeau, G., de Vernal., A., Devillers, R., Hillaire-Marcel, C., Loucheur, V., Mucci, A., Zhang, G., 1999. Caractérisation des sediments récents du Fjord de Saguenay (Québec) à partir de traceurs physiques, géochimiques, isotopiques et micropaléontologiques. Geog. Phys. Quat. 53, 339-350.

Takano, Y., Horiguchi, T., 2005. Acquiring scanning electron microscopical, light microscopical and multiple gene sequence data from a single dinoflagellate cell. J. Phycol., 42, 251-256.

Tappan, H., 1980. The Paleobiology of Plant Protists. Freeman, San Francisco, 977 pp.

Van Waveren, I.M., Marcus, N.H., 1993. Morphology of recent copepod egg envelopes from Turkey Point, Gulf of Mexico, and their implications for acritarch affinity. Spec. Pap.. Palaeont. 48, 111-124.

Vanhöffen, E., 1897. Die Fauna und Flora Gronlands. Gronland-Expedition der Gesellschaft fur Erkunde zu Berlin 1891-1893 2, 1-383.

Verhoeven, K., Louwye, S., Paez-Reyes, M., Mertens, K.N., Vercauteren, D., 2014. New acritarchs from the late Cenozoic of the southern North Sea Basin and the North Atlantic real. Palynology 38, 38-50.

Verleye, T., Mertens, K.N., Louwye, S., Arz, H.W., 2009. Holocene salinity changes in the southwestern Black Sea: A reconstruction based on dinoflagellate cysts. Palynology 33, 77100.

Verni, F., Rosati, G., 2011. Resting cysts: A survival strategy in Protozoa Ciliophora. Ital. J. of Zool. 78, 134-145.

Volk, R. 1905. Hamburgische Elb-Untersuchung VIII. Studien über die Einwirkung der Trockenperiode im Sommer 1904. Mitteilungen aus dem Naturhistorischen Museum in Hamburg 23, 1-101. 
Wang, B., Niu, T., Bhatti, M.Z., Chen, F., Wu, L., Chen, J., 2017. Identification of cyst wall proteins of the hypotrich ciliate Euplotes encysticus using a proteomics approach. J. Microbiol. 55, 545-553.

Warny, S., 2009. Species of the acritarch genus Palaeostomocystis Deflandre 1937: Potential indicators of neritic subpolar to polar environments in Antarctica during the Cenozoic. Palynology 33, 43-54.

Wilbert, N., Song, W., 2008. A further study on littoral ciliates (Protozoa, Ciliophora) near King George Island, Antarctica, with description of a new genus and seven new species. J. Nat. Hist. 42, 979-1012.

Williams, G.L., Fensome, R.A., MacRae, R.A., 2017. The Lentin and Williams index of fossil dinoflagellate cysts, 2017 edition. AASP Conrib. Ser. 48, 1-1097.

Willman, S., 2009. Morphology and wall structure of leiosphaeric and acanthomorphic acritarchs from the Ediacaran of Australia. Geobiology 7, 8-20.

Wright, R.R., 1907. The plankton of eastern Nova Scotia waters. An account of floating organisms upon which young food-fishes mainly subsist. Contrib. Can. Biol. Fish. 1, 1-19.

Wright, A.-D. G., Colorni, A., 2002. Taxonomic re-assignment of Cryptocaryon irritans, a marine fish parasite. Europ. J. Protistol. 37, 375-378.

Yi, Z., Dunthorn, M., Song, W., Stoeck, T., 2010. Increased taxon sampling using both unidentified environmental sequences and identified cultures improves phylogenetic inference in the Prorodontida (Ciliophora, Prostomatea). Mol. Phylogenet. Evol. 57, 937-941.

Zhang, Q., Yi, Z., Fan, X., Warren, A., Gong, J., Song, W., 2014. Further insights into the phylogeny of two ciliate classes Nassophorea and Prostomatea (Protista, Ciliophora). Mol. Phylogenet. Evol. 70, 162-170. 

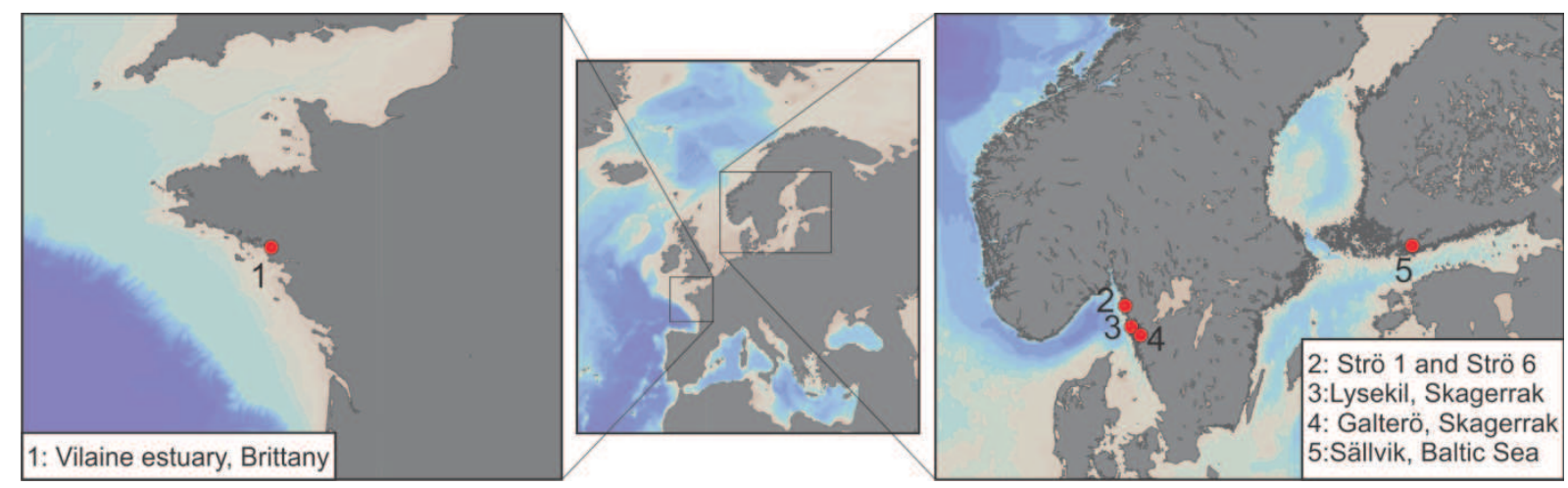

Fig. 1. Map showing the five sampling sites (red dots) of surface sediments in this study.1.

Vilaine estuary, Brittany; 2. stations 'Strö 1' and Strö 6', South of Havstenstund (Skagerrak, Sweden); 3. Lysekil, station 'Lyse 3' (Skagerrak, Sweden); 4. Galterö (Skagerrak, Sweden); 5. Sällvik, Pojo Bay (Baltic Sea, Finland). 


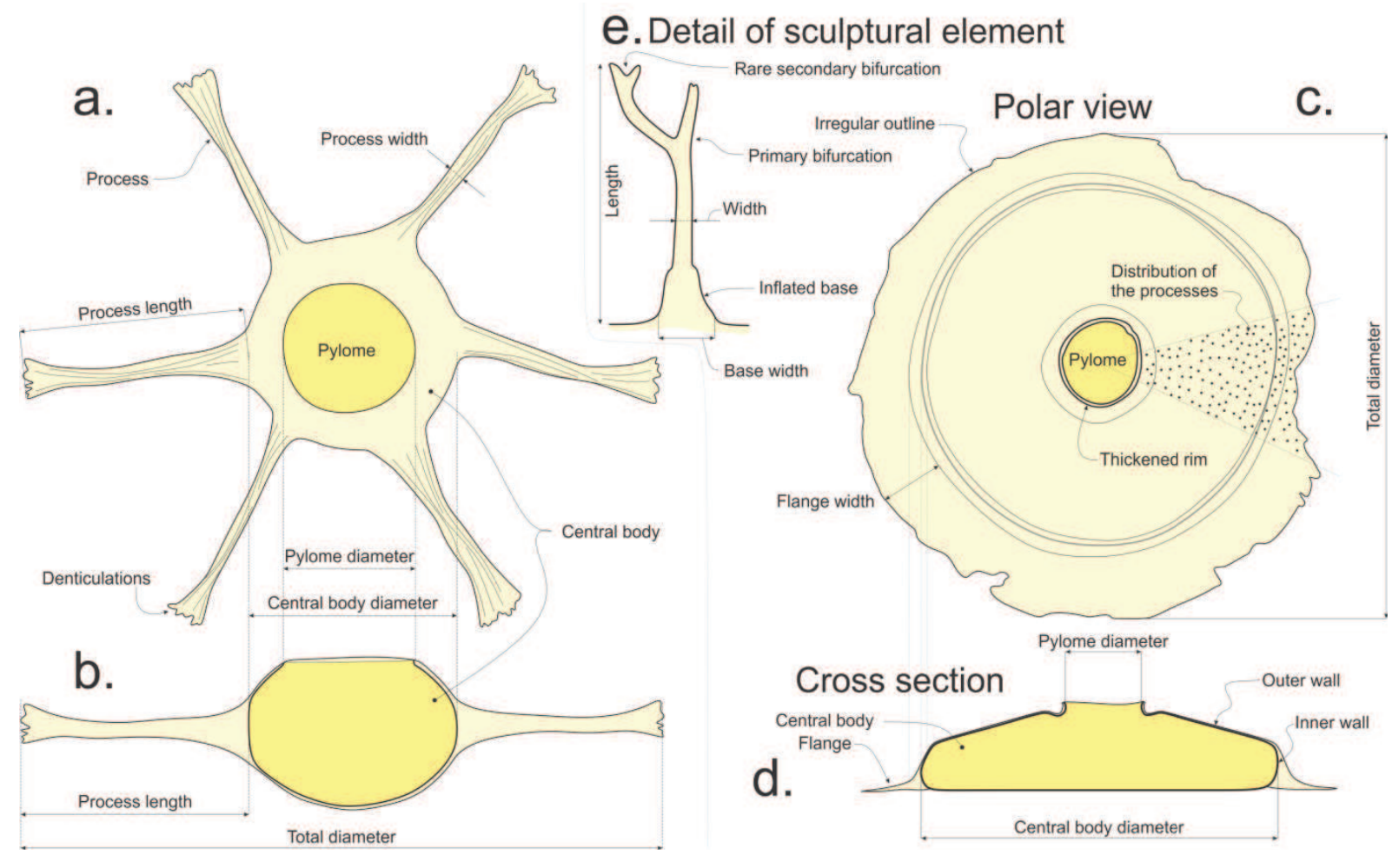

Fig. 2a-e. Schematic drawing of Hexasterias problematica $(a, b)$ and Halodinium verrucatum sp. nov. (c-e), depicting the morphological features discussed in text. 

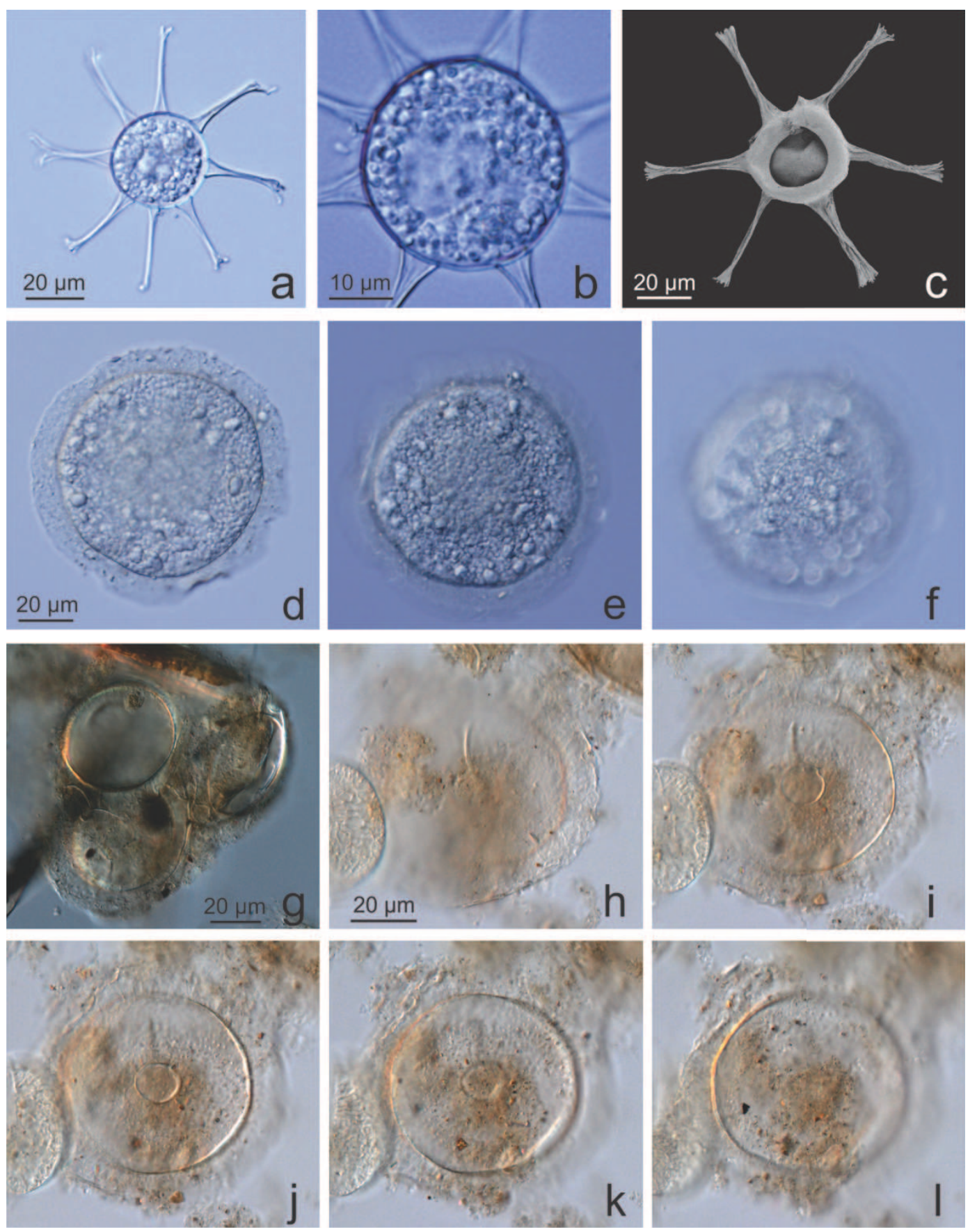

Fig. 3a-l. Hexasterias problematica (a-c) and Halodinium verrucatum sp. nov. (d-1), in LM (a-b, d-l) and SEM (c). a-b: cysts with cytoplasm from the Baltic Sea (Sällvik); c: empty cyst from the Skagerrak (Lyse 3); d-f: cysts with cytoplasm from the Skagerrak (Stro 1); g-l: empty cysts from the Skagerrak (Lyse 3), showing a cluster (g) and a specimen in polar view, obscured by amorphous organic matter. 


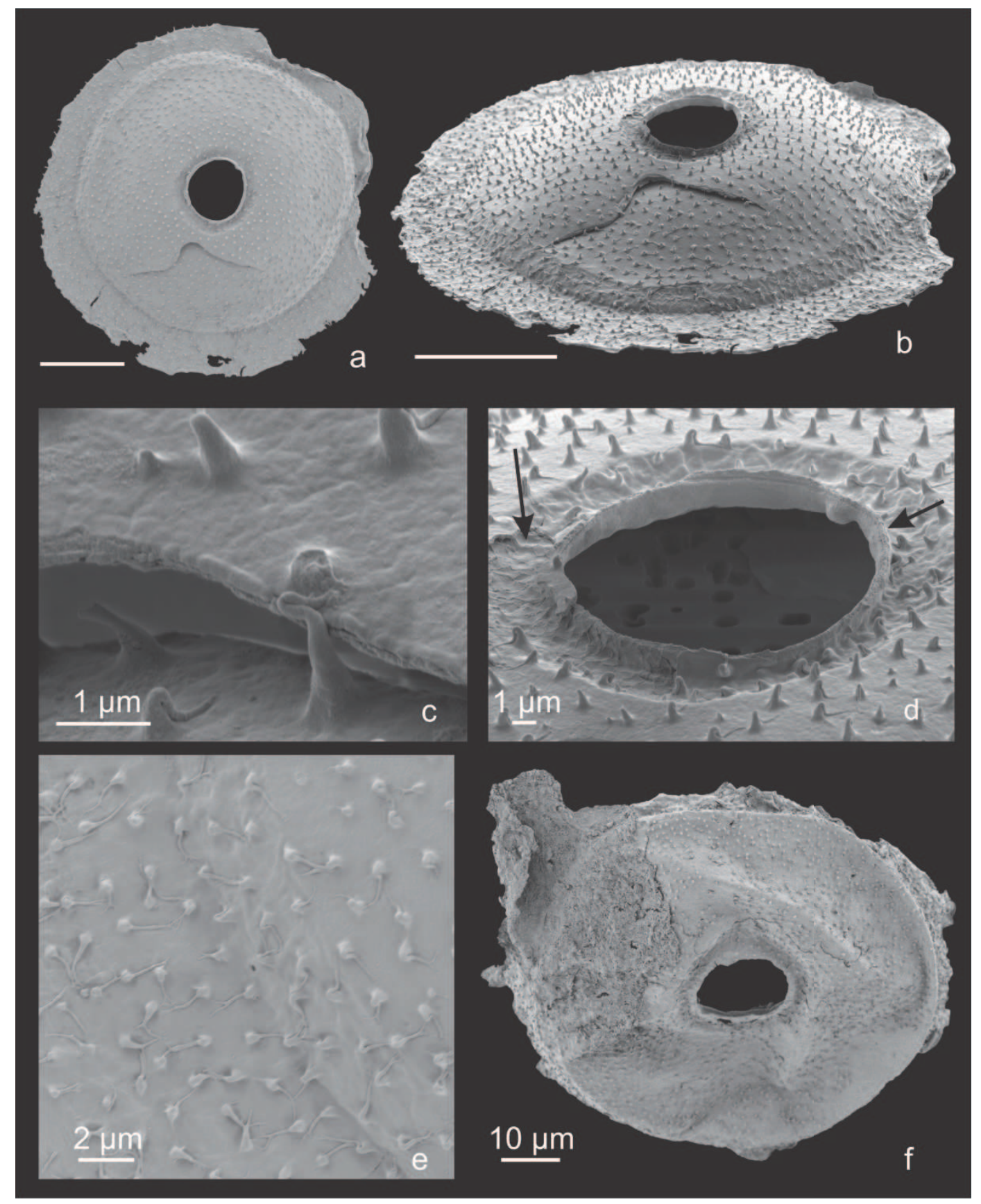

Fig. 4a-f. Halodinium verrucatum sp. nov., holotype from the Vilaine estuary (a-e) and specimen from Kaštela Bay, Croatia (f), in SEM. a: oral view; b: oblique oral view; c: detail of wall rupture and sculptural elements; $\mathbf{d}$ : detail of pylome, with arrows indicating the texture of the inner wall (left) and the thickened rim of the pylome (right); e: detail of scultural elements. Scale bar is $20 \mu \mathrm{m}$ unless otherwise indicated. 


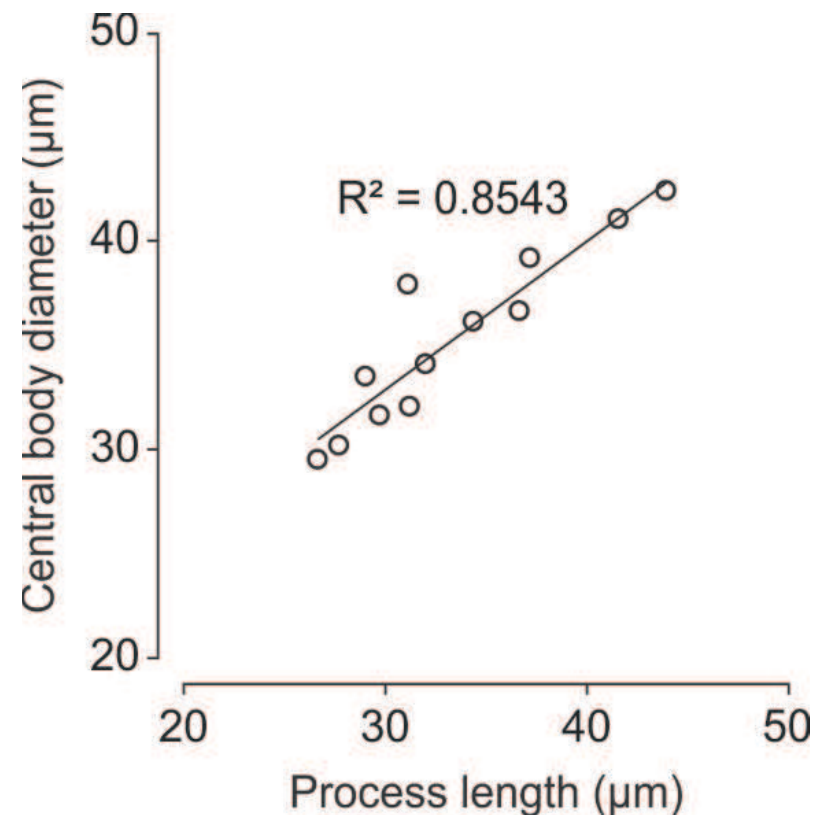

Fig. 5. Correlation of central body diameter and process length of Hexasterias problematica. 

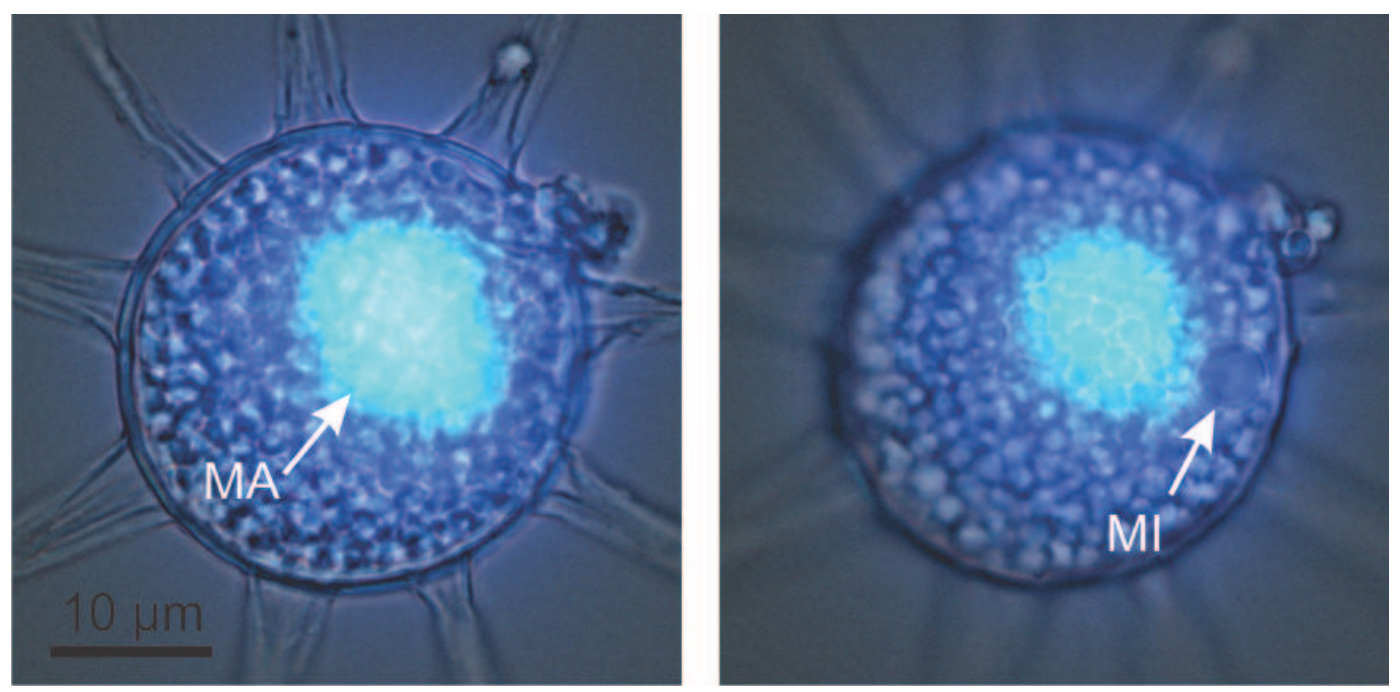

Fig. 6. DAPI-stained cell of Hexasterias problematica form the Vilaine Estuary (Brittany), showing micro (MI)- and macronucleus (MA). 


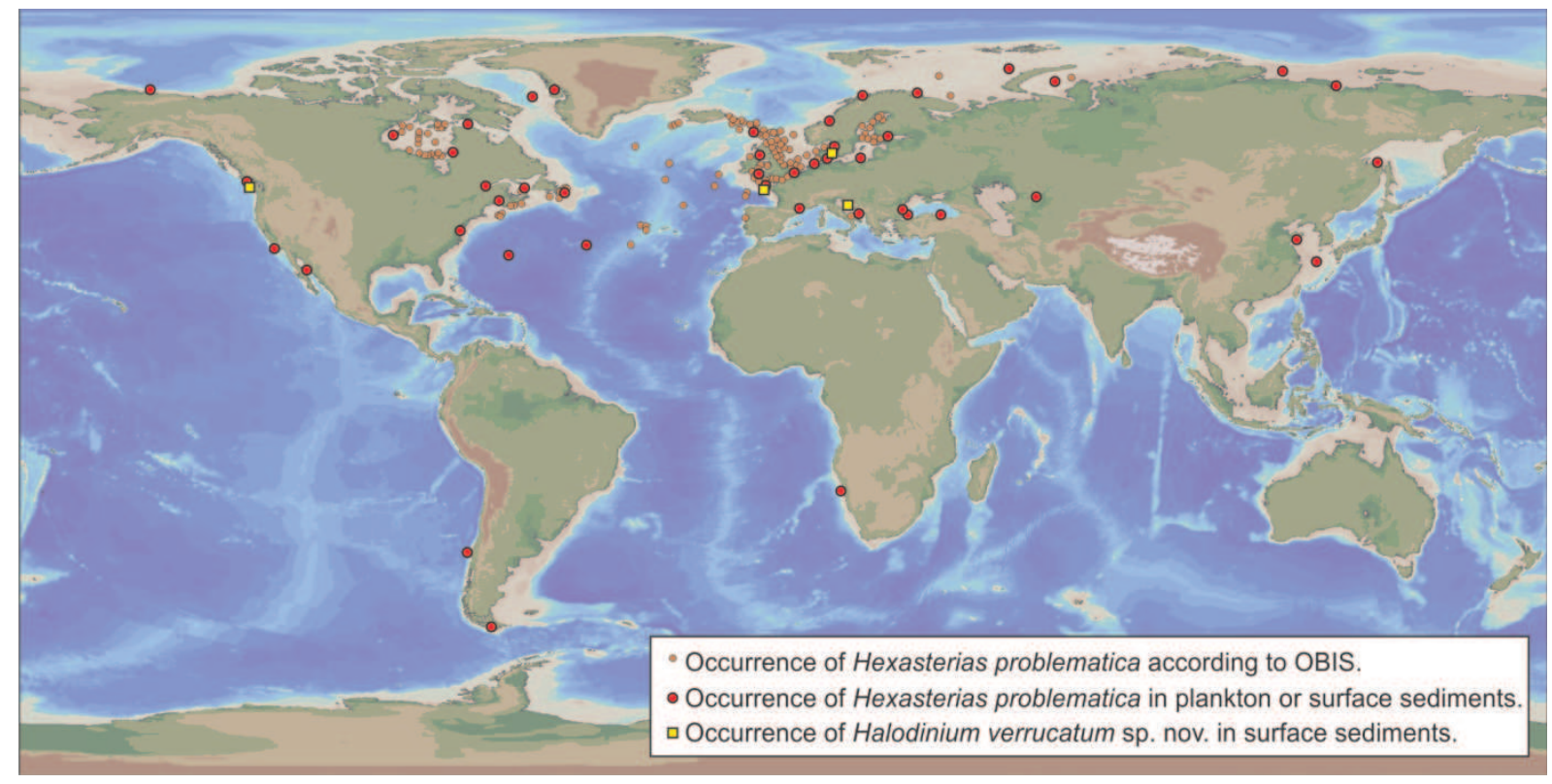

Fig. 7. Map showing the distribution of Hexasterias problematica (red and small brown circles) and

Halodinium verrucatum sp. nov. (yellow squares). The occurrences of Hexasterias problematica are based on Kubiszyn \& Svensen (2018), supplemented with additional published and personal observations (see section Occurrence and stratigraphic range in Species descriptions). The small brown circles represent occurrence data from OBIS, as in Kubiszyn \& Svensen (2018). 


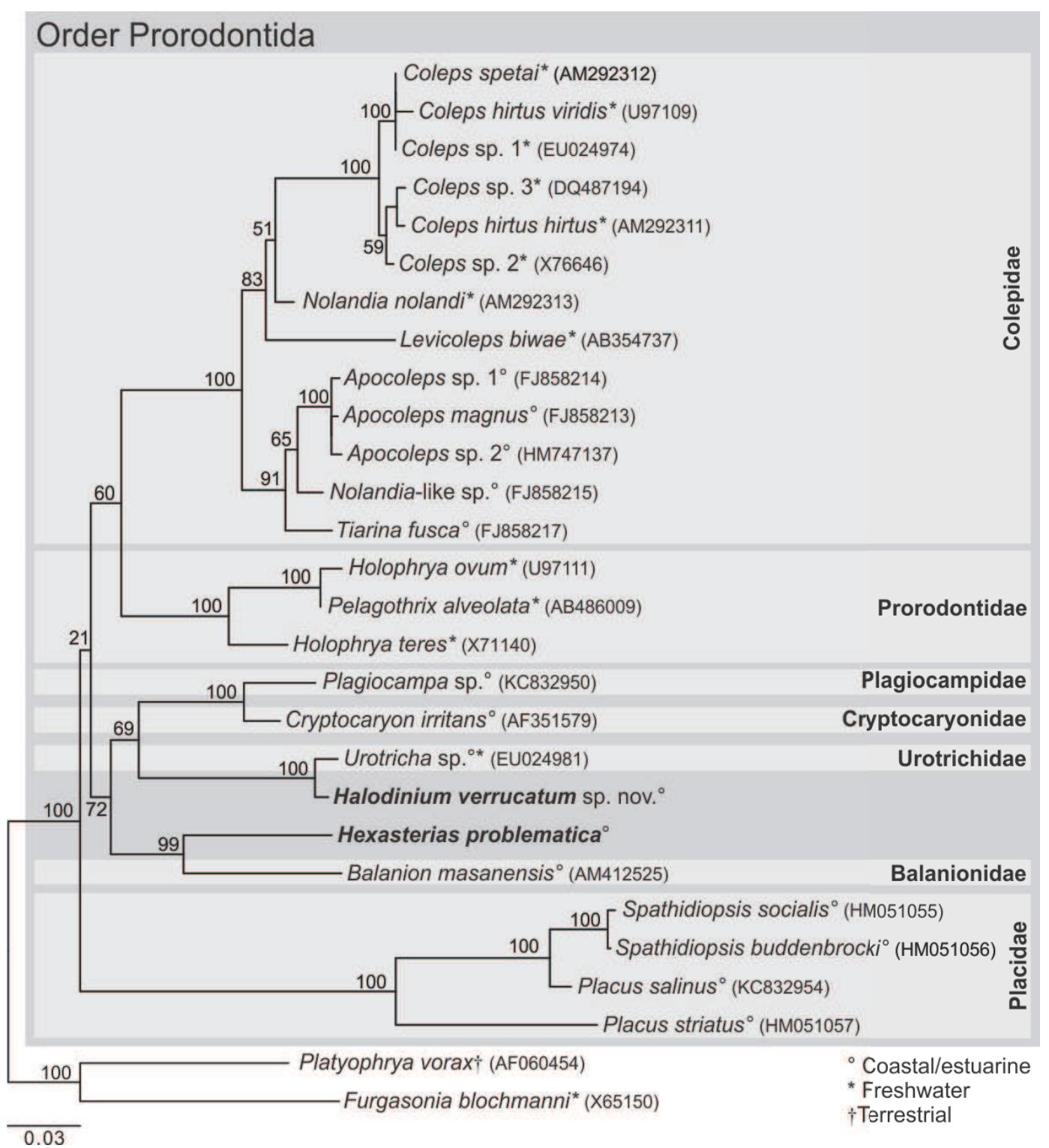

Fig. 8. Phylogenetic placement of Hexasterias problematica and Halodinium verrucatum sp. nov. based on SSU rDNA sequences, with indication of GenBank accession numbers, existing classification (e.g., Gao et al. 2016) and ecological preferences (e.g., Lynn 2008). 


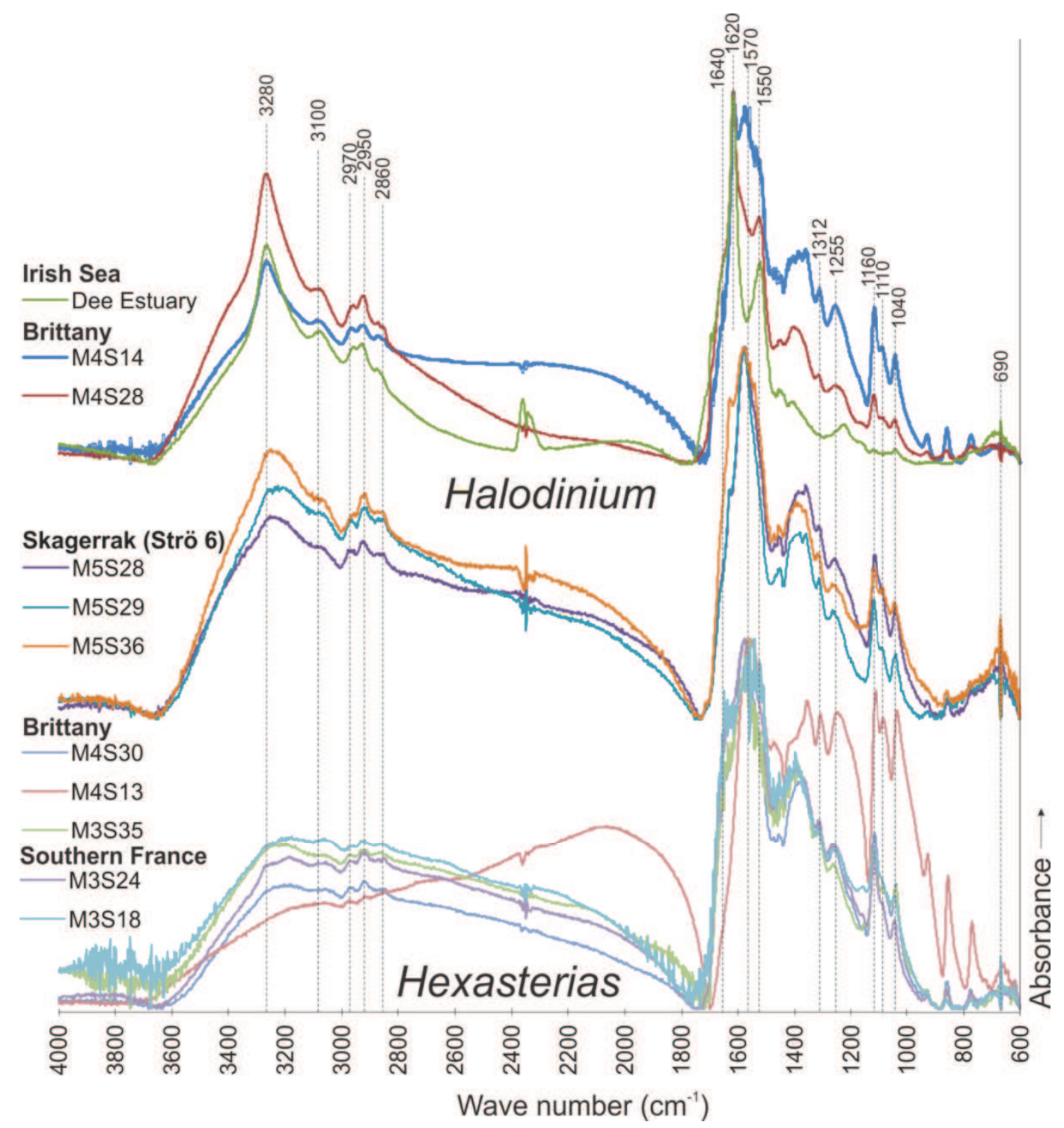

Fig. 9. Normalized micro-FTIR absorbance spectra of Halodinium spp. (Irish Sea and Brittany), Halodinium verrucatum sp. nov. (Strö 6) and Hexasterias problematica, with indication of the major absorptions (cf. Table 5). Specimen numbers (MxSy) refer to unique measurement codes. 


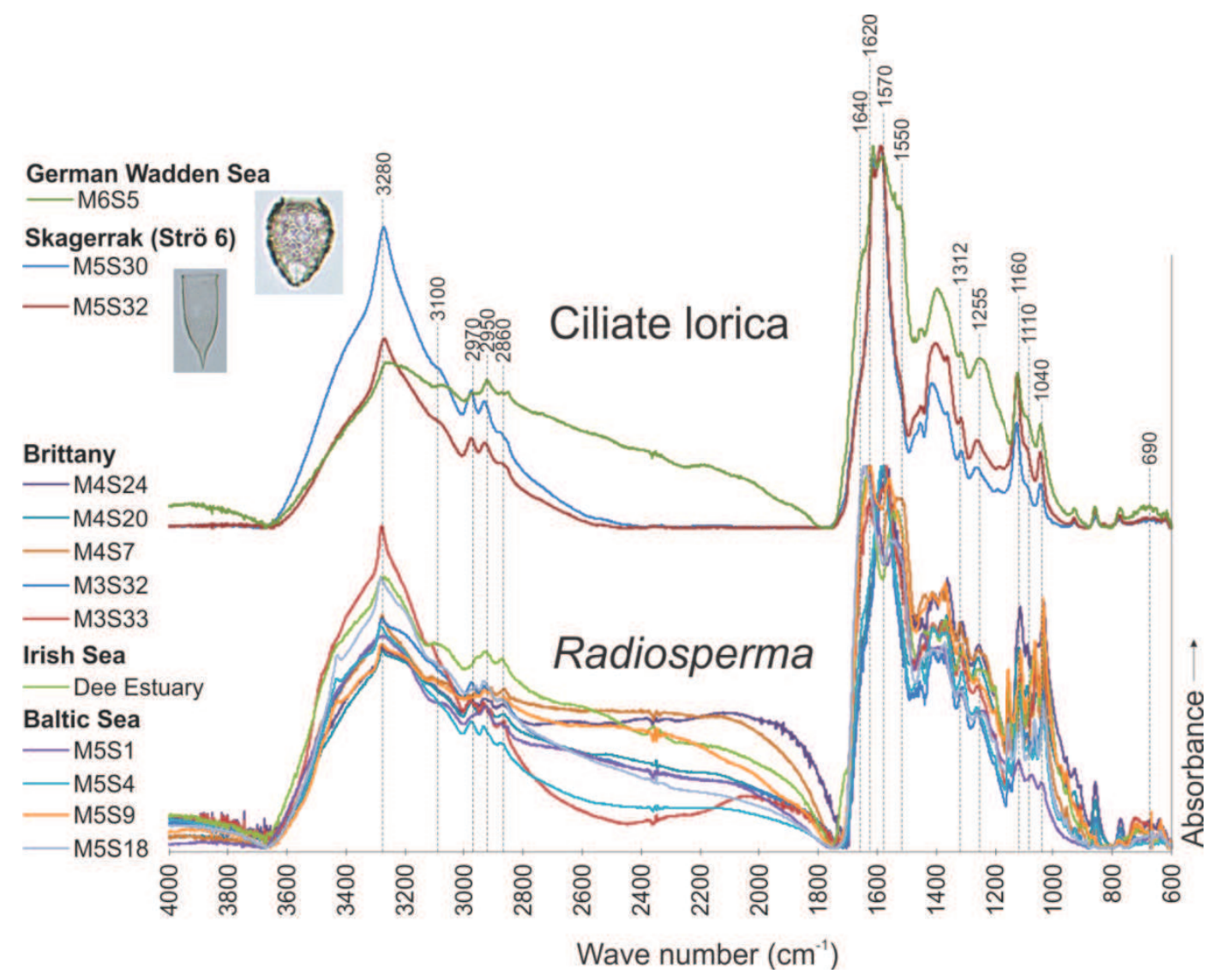

Fig. 10. Normalized micro-FTIR absorbance spectra of ciliate loricae (German Wadden Sea and Skagerrak) and Radiosperma corbiferum (Brittany, Irish and Baltic Seas), with indication of the major absorptions (cf. Table 5). Specimen numbers (MxSy) refer to unique measurement codes. 
Table 1. Region, site location, latitude, longitude and water depth of samples from Brittany, the Skagerrak and the Baltic Sea used in this paper.

\begin{tabular}{lllll}
\hline Region & Sampling site & $\begin{array}{l}\text { Latitude } \\
\left({ }^{\circ} \mathrm{N}\right)\end{array}$ & $\begin{array}{l}\text { Longitude } \\
\left({ }^{\circ} \mathrm{E}\right)\end{array}$ & $\begin{array}{l}\text { Water depth } \\
(\mathrm{m})\end{array}$ \\
\hline Brittany & Vilaine Estuary & 47.5 & 2.39 & 6 \\
Baltic Sea & Sällvik (Pojo bay, Finland) & 60.02 & 23.48 & 34.5 \\
Kattegatt & Galterö & 57.11 & 11.81 & 40.5 \\
Skagerrak & "Strö 1", South of Havstensund (Sweden) & 58.73 & 11.17 & 31 \\
Skagerrak & "Strö 6", west of Strömstad (Sweden) & 58.85 & 10.76 & 100 \\
Skagerrak & "Lyse 3" & 58.34 & 11.36 & 29 \\
\hline
\end{tabular}


Table 2. Morphometric data for Hexasterias problematica, based on material from Brittany and the Skagerrak.

\begin{tabular}{llllllll}
\hline & $\begin{array}{l}\text { Arithmetic } \\
\text { mean }\end{array}$ & Median & SD & CV & Min & Max & N \\
\hline Total diameter $(\mu \mathrm{m})$ & 102.2 & 99.1 & 14.9 & 14.58 & 82.8 & 130.2 & 12 \\
Pylome diameter $(\mu \mathrm{m})$ & 22.4 & 22.1 & 1.8 & 8.04 & 18.9 & 25.5 & 9 \\
Central body diameter $(\mu \mathrm{m})$ & 35.2 & 34.5 & 3.9 & 11.08 & 29.5 & 42.4 & 15 \\
Process length $(\mu \mathrm{m})$ & 33.4 & 31.6 & 5.5 & 16.47 & 26.6 & 43.9 & 12 \\
Process width $(\mu \mathrm{m})$ & 2.7 & 2.7 & 0.8 & 28.41 & 2 & 3.6 & 9 \\
Number of processes & 6.5 & 6 & 0.9 & 13.85 & 5 & 8 & 12 \\
Number of denticulations & 9.7 & 10 & 0.5 & 5.15 & 9 & 10 & 6 \\
\hline
\end{tabular}


Table 3. Morphometric data for Halodinium verrucatum sp. nov. from Brittany and the Skagerrak

\begin{tabular}{llllllll}
\hline & $\begin{array}{l}\text { Arithmetic } \\
\text { mean }\end{array}$ & Median & SD & CV & Min & Max & N \\
\hline Total diameter $(\mu \mathrm{m})$ & 70.2 & 67 & 8.5 & 12.1 & 60.4 & 87.5 & 21 \\
Pylome diameter $(\mu \mathrm{m})$ & 14.2 & 13.7 & 2 & 14.1 & 10.5 & 18.5 & 24 \\
Central body diameter $(\mu \mathrm{m})$ & 56.5 & 53.7 & 8.1 & 14.3 & 47 & 74 & 24 \\
Flange width $(\mu \mathrm{m})$ & 13.4 & 12.4 & 3.9 & 29.1 & 9.3 & 25.3 & 15 \\
Length of sculptural elements $(\mu \mathrm{m})$ & 1.7 & 1.7 & 0.2 & 9.4 & 1.6 & 2.1 & 10 \\
Width of sculptural elements $(\mu \mathrm{m})$ & 0.13 & 0.12 & 0.02 & 15.4 & 0.1 & 0.18 & 15 \\
Width of sculptural element basis $(\mu \mathrm{m})$ & 0.39 & 0.38 & 0.03 & 7.7 & 0.36 & 0.45 & 8 \\
Distance between sculptural elements $(\mu \mathrm{m})$ & 1.6 & 1.6 & 0.3 & 16 & 1.3 & 2.3 & 21 \\
\hline
\end{tabular}


Table 4. Comparison of diagnostic features of the species of Halodinium.

\begin{tabular}{|c|c|c|c|c|c|}
\hline Species & Halodinium major & Halodinium minor & Halodinium scopaeum & Halodinium eiriksonii & Halodinium verrucatum sp. nov. \\
\hline Body diameter & $104-116 \mu \mathrm{m}$ & $46-63 \mu \mathrm{m}$ & $21-24 \mu \mathrm{m}$ & $23.9-27.4 \mu \mathrm{m}$ & $47.0(56.5) 74.0 \mu \mathrm{m}$ \\
\hline Pylome diameter & $24-25 \mu \mathrm{m}$ & $11-22 \mu \mathrm{m}$ & $5.5-8.0 \mu \mathrm{m}$ & $4.6-8.8 \mu \mathrm{m}$ & $10.5(14.2) 18.5 \mu \mathrm{m}$ \\
\hline Max. flange width & $9-27 \mu \mathrm{m}$ & $4.5-9 \mu \mathrm{m}$ & $3-5.5 \mu \mathrm{m}$ & $1.6-6.8 \mu \mathrm{m}$ & $9.3(13.4) 25.3 \mu \mathrm{m}$ \\
\hline General shape & $\begin{array}{l}\text { Discoidal with circular polar outline and } \\
\text { irregular membranous flange. }\end{array}$ & $\begin{array}{l}\text { Discoidal with circular polar outline and } \\
\text { irregular membranous flange. }\end{array}$ & $\begin{array}{l}\text { Central body has a strong polar } \\
\text { compression and circular to subcircular } \\
\text { outline in polar view. }\end{array}$ & $\begin{array}{l}\text { Small, polar compressed, with circular to } \\
\text { subcircular outline. }\end{array}$ & $\begin{array}{l}\text { polar compressed cyst with a circular to } \\
\text { subcircular outline in polar view. }\end{array}$ \\
\hline Wall & - & - & $\begin{array}{l}\text { Bilayered, pale yellow-brown. } \\
\text { Periphragm much thinner than } \\
\text { endophragm, to which it is appressed } \\
\text { except at ambitus. }\end{array}$ & $\begin{array}{l}\text { Bilayered, outer wall is appressed to the } \\
\text { inner wall over the greater part of the cyst } \\
\text { body. }\end{array}$ & Bilayered, \\
\hline $\begin{array}{l}\text { Nature of the wall } \\
\text { and ornamentation }\end{array}$ & $\begin{array}{l}\text { The wall of the main body has a } \\
\text { granulate or occasionally rugulate surface }\end{array}$ & $\begin{array}{l}\text { The wall of the main body has a smooth } \\
\text { surface }\end{array}$ & $\begin{array}{l}\text { Smooth or faintly scabrate. Periphragm } \\
\text { visible as small wrinkles over the surface } \\
\text { of the endocyst. }\end{array}$ & $\begin{array}{l}\text { Scabrate to smooth outer wall has a } \\
\text { rugulate surface consisining of } \\
\text { occasionally anastomosing wrinkle-like } \\
\text { ridges. }\end{array}$ & $\begin{array}{l}\text { Central body ornamented with low ridges } \\
\text { forming an irregular reticulum, and is } \\
\text { covered over the polar region with a thin, } \\
\text { hyaline outer layer ornamented with } \\
\text { discrete, bifurcating sculptural elements. }\end{array}$ \\
\hline Pylome & $\begin{array}{l}\text { Central pylome with well-defined ridge } \\
\text { on, or close to edge of pylome. } \\
\text { Operculum often in place; circular with a } \\
\text { smooth edge that is usually thickened, } \\
\text { although the thickening may occur a few } \\
\text { micrometers away from the pylome on } \\
\text { the main body. }\end{array}$ & $\begin{array}{l}\text { Central pylome present, with operculum } \\
\text { often in place. The central pylome is } \\
\text { circular with a smooth edge that is } \\
\text { occasionally thickened. }\end{array}$ & $\begin{array}{l}\text { Pylome located centrally and circular or } \\
\text { subcircular, with an entire and usually } \\
\text { unthickened margin. }\end{array}$ & Circular without operculum. & $\begin{array}{l}\text { A central pylome with a thickened rim; } \\
\text { operculum not observed. }\end{array}$ \\
\hline Ambital flange & $\begin{array}{l}\text { The surrounding membrane extends } \\
\text { around the main body and is thin, pale } \\
\text { and often broken or torn }\end{array}$ & $\begin{array}{l}\text { The surrounding membrane extends } \\
\text { around the main body and is thin, pale } \\
\text { and often broken or torn. }\end{array}$ & $\begin{array}{l}\text { Diophanous flange of approximately } \\
\text { constant width; its outer margin usually } \\
\text { ragged but may be partially entire on } \\
\text { some specimens. }\end{array}$ & $\begin{array}{l}\text { At the periphery of the cyst, the outer } \\
\text { wall forms a collar-like ambital flange, } \\
\text { consisting of irregular septate or foldlike } \\
\text { structures. }\end{array}$ & $\begin{array}{l}\text { The outer layer forms near the margin of } \\
\text { the central body a wrinkled, diaphanous } \\
\text { collar-like outer flange with a varying } \\
\text { width. }\end{array}$ \\
\hline Reference & Bujak (1984) & Bujak (1984) & Head (1993) & Verhoeven et al. (2013) & This paper \\
\hline
\end{tabular}


Table 5. FTIR assignments of functional groups present in Halodinium spp. and Hexasterias problematica (absorptions in bold are shown on Figs. 9 and 10).

\begin{tabular}{lll}
\hline Wavenumber $\left(\mathrm{cm}^{-1}\right)$ & Assignment* & Comments \\
\hline$\sim 3400$ & $v \mathrm{OH}$ & shoulder \\
$\mathbf{3 2 8 0}$ & $\mathbf{v N H}$ & \\
$\mathbf{3 1 0 0}$ & $\mathbf{v N H}$ & \\
$\mathbf{2 9 7 0}$ & $\mathbf{v C H 3}$ & \\
$\mathbf{2 9 5 0}$ & $\mathbf{v C H 2}$ & \\
$\mathbf{2 8 6 0}$ & $\mathbf{v C H 3}$ & \\
$\mathbf{1 6 4 0}$ & $\mathbf{v C}=\mathbf{O}$ & \\
$\mathbf{1 6 2 0}$ & $\mathbf{v C}=\mathbf{O}$ & Amide I \\
$\mathbf{1 5 8 0}, \mathbf{1 5 5 0}$ & $\mathbf{v C N}+\boldsymbol{\delta N H}$ & Amide II \\
1420 & $\delta \mathrm{CH} \mathrm{H}_{2}$ & \\
1370 & $\delta \mathrm{CH}+\delta \mathrm{C}-\mathrm{CH}$ & \\
$\mathbf{1 3 1 2}$ & $\mathbf{v C N}+\mathbf{\delta N H}$ & Amide III \\
$\mathbf{1 2 5 5}$ & $\boldsymbol{\delta} \mathbf{N H}$ & \\
$\mathbf{1 1 6 0}$ & $\mathbf{v C}-\mathbf{O}-\mathbf{C}$ & Ring \\
$\mathbf{1 1 1 0}$ & $\mathbf{v C}-\mathbf{O}$ & \\
$\mathbf{1 0 4 0}$ & $\mathbf{v C}-\mathbf{O}$ & \\
930 & $\gamma \mathrm{CH} 3$ & \\
860,770 & $\rho \mathrm{CH} 2$ & Amide V \\
$\mathbf{6 9 0}$ & $\gamma \mathbf{N H}$ & $\gamma$ \\
\hline
\end{tabular}

$* v$ means bond stretching, $\delta$ means deformation, $\gamma$ means wagging and $\rho$ means rocking of a bond within a molecule. 